\title{
Consistent simulation of bromine chemistry from the marine boundary layer to the stratosphere - Part 1: Model description, sea salt aerosols and pH
}

\author{
A. Kerkweg ${ }^{1,2}$, P. Jöckel ${ }^{1}$, A. Pozzer ${ }^{1}$, H. Tost ${ }^{1}$, R. Sander ${ }^{1}$, M. Schulz ${ }^{3}$, P. Stier ${ }^{4}$, E. Vignati ${ }^{5}$, J. Wilson ${ }^{5}$, and \\ J. Lelieveld ${ }^{1}$ \\ ${ }^{1}$ MPI for Chemistry (Otto Hahn Institute), Atmospheric Chemistry Department, P.O. Box 3060, 55020 Mainz, Germany \\ ${ }^{2}$ Institute for Atmospheric Physics, University of Mainz, Mainz, Germany \\ ${ }^{3}$ Laboratoire des Sciences du Climat et de l'Environnement, CEA-IPSL, Saclay, France \\ ${ }^{4}$ Atmospheric, Oceanic and Planetary Physics, University of Oxford, Oxford, UK \\ ${ }^{5}$ Joint Research Centre, Institute of Environment and Sustainability, Ispra, Italy
}

Received: 26 February 2008 - Published in Atmos. Chem. Phys. Discuss.: 14 April 2008

Revised: 12 August 2008 - Accepted: 20 August 2008 - Published: 15 October 2008

\begin{abstract}
This is the first article of a series presenting a detailed analysis of bromine chemistry simulated with the atmospheric chemistry general circulation model ECHAM5/MESSy. Release from sea salt is an important bromine source, hence the model explicitly calculates aerosol chemistry and phase partitioning for coarse mode aerosol particles. Many processes including chemical reaction rates are influenced by the particle size distribution, and aerosol associated water strongly affects the aerosol $\mathrm{pH}$. Knowledge of the aerosol $\mathrm{pH}$ is important as it determines the aerosol chemistry, e.g., the efficiency of sulphur oxidation and bromine release. Here, we focus on the simulated sea salt aerosol size distribution and the coarse mode aerosol $\mathrm{pH}$.

A comparison with available field data shows that the simulated aerosol distributions agree reasonably well within the range of measurements. In spite of the small number of aerosol $\mathrm{pH}$ measurements and the uncertainty in its experimental determination, the simulated aerosol $\mathrm{pH}$ compares well with the observations. The aerosol $\mathrm{pH}$ ranges from alkaline aerosol in areas of strong production down to $\mathrm{pH}$-values of 1 over regions of medium sea salt production and high levels of gas phase acids, mostly polluted regions over the oceans in the Northern Hemisphere.
\end{abstract}

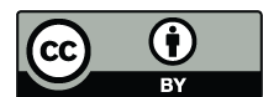

Correspondence to: A. Kerkweg (akerkweg@mpch-mainz.mpg.de)

\section{Introduction}

Halogen containing compounds that photochemically decompose in the stratosphere contribute to catalytic ozone destruction. Reactive bromine is less easily deactivated into reservoir species compared to chlorine, hence its ozone destroying efficiency is about 50 times higher (Brasseur and Solomon, 2005). Though less dramatic, similar processes have been shown to occur in the marine boundary layer, as indicated by the depletion of chlorine and bromine in sea salt aerosol particles (Sander et al., 2003). In contrast to prior model studies investigating only one of these two phenomenons/domains, the model simulation discussed here is dedicated to consistently simulate bromine chemistry from the boundary layer to the stratosphere. We used the atmospheric chemistry general circulation model (ACGCM) ECHAM5/MESSy (http://www.messy-interface.org), because this model is able to consistently simulate chemistry in this entire domain (Jöckel et al., 2006). For a list of abbreviations, see Table 1. One aim of this work is to compute both column integrated and vertically resolved reactive bromine (e.g. BrO) concentrations that can be directly compared to global satellite measurements (Wagner et al., 2001). The latter will be pursued in a follow-up article, whereas here we focus on the marine boundary layer.

One important bromine source is sea salt aerosol. Therefore, an adequate aerosol representation must be available in the model, on which we focus in the present article. In recent years much progress has been made in incorporating

Published by Copernicus Publications on behalf of the European Geosciences Union. 
Table 1. List of all abbreviations used in this article.

\begin{tabular}{|c|c|}
\hline abbreviation & \\
\hline AC-GCM & Atmospheric Chemistry General Circulation Model \\
\hline ACE 1 & First Aerosol Characterisation Experiment \\
\hline ADM & aerosol dynamical model \\
\hline AEROCE & Atmosphere-Ocean Chemistry Experiment \\
\hline AeroCom & Aerosol Comparison experiment \\
\hline AIRSEA & MESSy submodel: trace gas air-sea exchange \\
\hline $\mathrm{BC}$ & black carbon (aerosol component, M7) \\
\hline CLOUD & MESSy submodel: cloud microphysics \\
\hline CONVECT & MESSy submodel: convection parameterisation \\
\hline CVTRANS & MESSy submodel: convective transport of tracers \\
\hline DMS & dimethyl sulphide \\
\hline DOE-EML & Department Of Energy, Environmental Measurements Laboratory \\
\hline DRYDEP & MESSy submodel: dry deposition of gases and aerosols \\
\hline DU & dust (aerosol component, M7) \\
\hline E5/M1 & ECHAM5/MESSy version 1 \\
\hline $\mathrm{E} 5 / \mathrm{M} 1^{+}$ & extended ECHAM5/MESSy1 version, used in this study \\
\hline ECHAM5 & GCM (MPI for Meteorology, Hamburg, Germany) \\
\hline ECHAM5-HAM & ECHAM5 version including the HAM \\
\hline ECMWF & European Centre of Medium-range Weather Forecasts \\
\hline EMEP & European Monitoring and Evaluation Programme \\
\hline $\mathrm{H} 2 \mathrm{O}$ & MESSy submodel: chemical tendency of $\mathrm{H}_{2} \mathrm{O}$ and feedback \\
\hline HAM & Hamburg Aerosol Model (based on the ADM M7+sources and sinks) \\
\hline HETCHEM & MESSy submodel: heterogeneous chemistry \\
\hline IMPROVE & Interagency Monitoring of Protected Visual Environments \\
\hline JVAL & MESSy submodel: photolysis rates \\
\hline L87/L90 & abbr. for vertical number of layers ( $L 87=87$ vertical layers) \\
\hline LNOX & MESSy submodel: Lightning $\mathrm{NO}_{\mathrm{x}}$ \\
\hline LWC & liquid water content \\
\hline M7 & MESSy submodel: an ADM \\
\hline MAECHAM5 & middle atmosphere setup of ECHAM5 \\
\hline MBL & marine boundary layer \\
\hline MECCA(-AERO) & MESSy submodel: gas and aerosol phase chemistry \\
\hline MESSy & Modular Earth Submodel System \\
\hline $\mathrm{OC}$ & organic carbon (aerosol component, M7) \\
\hline ODE & ordinary differential equation \\
\hline OFFLEM & MESSy submodel: offline emissions \\
\hline ONLEM & MESSy submodel: online emissions \\
\hline PDF & Probability Density Functions \\
\hline PSC & MESSy submodel: polar stratospheric clouds \\
\hline RAD4ALL & MESSy submodel: radiation \\
\hline QBO & Quasi-Biennial Oscillation (process and MESSy submodel) \\
\hline SEAREX & the sea/air exchange program \\
\hline SCAV & MESSy submodel: scavenging and cloud chemistry of gases and aerosol particles \\
\hline SEDI & MESSy submodel: sedimentation of aerosol particles \\
\hline SS & sea salt (aerosol component, M7) \\
\hline SU & sulphate (aerosol component, M7) \\
\hline TNUDGE & MESSy submodel: tracer nudging \\
\hline TROPOP & MESSy submodel: tropopause diagnostic \\
\hline
\end{tabular}


aerosols into global models (Lauer et al., 2005; Stier et al., 2005; Gong et al., 2003; Spracklen et al., 2005), following the overall tendency in atmospheric modelling to include additional details of processes. Most of these models focus on aerosol microphysical processes, and neglect or simplify aerosol chemistry. For example, Stier et al. (2005) included only the phase transition of sulphate, i.e. the condensation of gas phase acids onto aerosol modes/bins; Lauer et al. (2005) used thermodynamic equilibrium chemistry. In our simulation, gas and aerosol phase chemistry is calculated in great detail (Kerkweg et al., 2007). We prognostically calculate the chemistry in the aerosol phase, i.e. without equilibrium assumptions using an explicit aqueous phase mechanism for the reactions in the coarse mode aerosol, the heterogeneous reactions on the coarse mode and the phase transitions. To our knowledge, this is the first global simulation attempting this in such detail. One of the advantages of this approach is that the $\mathrm{H}^{+}$concentration is included like other chemical species, which allows a prognostic calculation of the aerosol $\mathrm{pH}$.

The chemistry releasing bromine from the aerosol is strongly $\mathrm{pH}$ dependent, as bromine is efficiently released from acidified aerosol $(\mathrm{pH}<5.5)$ only. In fact, all aerosol chemistry depends on the aerosol $\mathrm{pH}$. In turn, the $\mathrm{pH}$ is influenced by the size distribution and the liquid water content of the aerosol particles (von Glasow and Sander, 2001). Since the sea salt aerosol mass is dominated by the coarse size fraction, the particle distribution and the aerosol $\mathrm{pH}$ for coarse mode aerosol are evaluated here.

Section 2 gives a description of the model used for this study with a special focus on the aerosol dynamical model (Sect. 2.4) and the aerosol chemistry model (Sect. 2.5). In Sect. 3 we provide an overview of the simulated aerosol distributions (Sect. 3.1) and discuss the simulated aerosol pHvalues (Sect. 3.2) before we draw our conclusions in Sect. 4.

\section{Model description}

For this study we used the atmospheric chemistry general circulation model (AC-GCM) ECHAM5/MESSy1 (E5/M1). ECHAM5 is the 5th generation European Centre Hamburg GCM (Roeckner et al., 2003, 2004). It is coupled to the Modular Earth Submodel System (MESSy) (Jöckel et al., 2005) which includes atmospheric chemistry and dynamics related submodels. The coupled E5/M1 model has been extensively evaluated by Jöckel et al. (2006).

To adapt the model to the needs of this study we introduced one important change. Since one of the main foci of the present simulation is bromine chemistry in the marine boundary layer and in the free troposphere, a model providing a higher resolution of the lower part of the atmosphere is desirable. For this, we applied a vertical resolu- tion with 87 layers (L87) on a hybrid-pressure grid reaching from the surface up to $0.01 \mathrm{hPa}(\approx 80 \mathrm{~km}$ altitude) as available in the ECHAM5 version 5.3.02. This resolution divides the boundary layer into more vertical layers than the L90 setup (used in the evaluation of Jöckel et al. (2006)). Hence, on average the marine boundary layer is described by 4 model layers. While the L 87 setup has a much better resolution in the lowest part of the atmosphere, the resolution of the L90 setup is better in the upper troposphere and stratosphere. A figure illustrating this can be found in the supplement (http://www.atmos-chem-phys.net/8/5899/2008/ acp-8-5899-2008-supplement.zip). Referring to the physical description the extended MESSy version $\left(\mathrm{M}^{+}\right)$, used for this study, is basically the same as MESSy version 1 (M1) described and evaluated in Jöckel et al. (2006).

\subsection{Model setup}

We discuss two simulations in this paper. First we repeated the evaluation simulation of Jöckel et al. (2006) to show that the model with the L87 vertical resolution setup produces comparable results to the L90 setup used by Jöckel et al. (2006). Hereafter this simulation is referred to as S-new. It was performed for the years 1998-2000. The second simulation will be denoted as S-hal simulation. It is the main simulation discussed in this series of articles, and it comprises explicit aerosol and bromine chemistry calculations. S-hal covers the period of January 1998 to December 2000. The first two years are used as model spin up (especially needed to ensure that the aerosol distribution and the aerosol chemistry are in dynamic equilibrium), and the year 2000 is analysed here.

The resolution is T42L87MA (MA stands for Middle Atmosphere, see Giorgetta et al., 2002; 2006). The horizontal resolution (T42) corresponds to a quadratic Gaussian grid of approximately $2.8^{\circ} \times 2.8^{\circ}$ (same as used by Jöckel et al., 2006) in longitude and latitude. The model timestep is $720 \mathrm{~s}$. To capture diurnal cycles, results are sampled as 5-hourly instantaneous output for almost all fields. This enables us to resolve an hourly diurnal cycle every 5 days of the simulation.

Jöckel et al. (2006) and Giorgetta et al. (2006) showed that MAECHAM5 is able to produce a selfconsistent QuasiBiennial Oscillation (QBO). Since we are in the present study not primarily interested in showing that the QBO is developing in the model by itself, it was additionally forced by the MESSy submodel QBO to yield the observed QBO phase.

In addition, temperature, vorticity, divergence and the logarithm of the surface pressure of the model have been nudged towards the analysis data from the European Centre of Medium-range Weather Forecasts (ECMWF) operational weather forecast model to represent the observed meteorology in the troposphere (Jeuken et al., 1996; Jöckel et al., 2006). The nudging was applied from above the boundary 
layer up to $200 \mathrm{hPa}$, thus the stratosphere as well as the boundary layer are calculated freely.

Most emissions are calculated from monthly offline fields using the submodel OFFLEM (Kerkweg et al., 2006b). For a detailed description of all submodels mentioned here see Jöckel et al. (2006). A list of annually integrated emission fluxes of most trace gases can be found in the supplement of Pozzer et al. (2007). To calculate online emissions for oceanic DMS (dimethyl sulphide), NO, isoprene and aerosols the MESSy submodel ONLEM (Kerkweg et al., $2006 \mathrm{~b}$ ) is used. The aerosol emissions are further described in the section about the aerosol model M7 (Sect. 2.4). 4.2 $\mathrm{Tg} \mathrm{NO}_{\mathrm{x}}$ per year are produced by lightning (submodel $\mathrm{LNO}_{\mathrm{X}}$, Tost et al., 2007).

For some trace gases the emission fluxes are highly uncertain, while the atmospheric concentrations in the boundary layer are relatively well known. Thus the mixing ratios of $\mathrm{N}_{2} \mathrm{O}, \mathrm{CH}_{4}, \mathrm{CFCl}_{3}, \mathrm{CH}_{3} \mathrm{CCl}_{3}, \mathrm{CCl}_{4}, \mathrm{CF}_{2} \mathrm{ClBr}, \mathrm{CF}_{3} \mathrm{Br}, \mathrm{H}_{2}$, $\mathrm{CO}_{2}, \mathrm{SF}_{6}, \mathrm{CH}_{3} \mathrm{Cl}$ and $\mathrm{CH}_{3} \mathrm{Br}$ are nudged towards the observed values in the lowest model layer using the submodel TNUDGE (Kerkweg et al., 2006b). To improve the emissions of acetone and methanol from the ocean (Pozzer et al., 2007), the submodel AIRSEA is used (Pozzer et al., 2006).

Dry deposition of gas phase species and aerosol particles and sedimentation of aerosol particles are calculated by the MESSy submodels DRYDEP and SEDI, respectively (Kerkweg et al., 2006a).

Cloud formation is calculated by the submodels CLOUD and CONVECT (Tost et al., 2006b, 2007). Convective transport of trace gases and aerosol particles is included via the submodel CVTRANS. Scavenging, cloud chemistry and wet deposition are calculated by SCAV (Tost et al., 2006a). Gas and aerosol phase chemistry are simulated by MECCA(AERO) (Sander et al., 2005; Kerkweg et al., 2007). Photolysis rates required by MECCA are calculated with the submodel JVAL following the approach of Landgraf and Crutzen (1998). All tendencies of the gaseous $\mathrm{H}_{2} \mathrm{O}$ tracer are fed back to the specific humidity by the submodel $\mathrm{H}_{2} \mathrm{O}$, e.g. the effect of the methane oxidation or the tendencies due to transport, cloud droplet evporation etc. Heterogeneous reaction rates and the partitioning of total water into water vapour, liquid water and ice for polar stratospheric clouds (PSCs) as well as outside the PSC region, are accounted for in the submodels PSC (Buchholz, 2005) and HETCHEM, respectively. Aerosol microphysics is calculated using the submodel M7 (see Sect. 2.4).

The temperature tendencies due to radiative heating (submodel RAD4ALL) are calculated by using the onlinecalculated mixing ratios of $\mathrm{CO}_{2}, \mathrm{~N}_{2} \mathrm{O}, \mathrm{CFCl}_{3}, \mathrm{CF}_{2} \mathrm{Cl}_{2}$, cloud cover, water vapour, cloud water content, and cloud ice. For the aerosol radiative effects the same aerosol climatology is used as in Jöckel et al. (2006).

In addition to the submodels listed above, we included several diagnostic submodels. The only one important for the present analysis is TROPOP which diagnoses the tropopause and the boundary layer height.

\subsection{Hardware}

All simulations were performed on the IBM pSeries "Regatta" system based on Power 4 processor technology at the Max Planck computer center Garching. We used 256 CPUs ( 8 compute nodes). One month simulation time of the reference simulation required a wall-clock time of approximately $14 \mathrm{~h}$. The most demanding process is the aerosol chemistry, a sensitivity simulation not including the explicit aerosol chemistry only required half of the CPU time of the reference simulation.

\subsection{Comparison to the evaluated model results}

Because some important changes have been applied between the model setup used by Jöckel et al. (2006) and the model setup discussed here, a comparison of the results obtained by both model configurations with the same setup is required. Thus a simulation (S-new), with the setup as described by Jöckel et al. (2006) for the S2 simulation, i.e. using the same submodels and namelist settings, was performed. The main difference is the model resolution (T42L87MA versus T42L90MA) and the application of some additional diagnostic tools. Overall the results of both simulations agree well within the expected uncertainties. The electronic supplement (http://www.atmos-chem-phys.net/8/5899/2008/ acp-8-5899-2008-supplement.zip) includes almost all figures corresponding to those in Jöckel et al. (2006).

\subsection{The microphysical aerosol model M7}

A major source of bromine in the atmosphere is the release from sea salt. Kerkweg et al. (2007) describe the submodel MECCA-AERO calculating the release via an explicit gas and aerosol phase chemistry mechanism. One important input parameter for these calculations is the aerosol distribution, which is required by MECCA-AERO, and is computed by an aerosol dynamical model (ADM). The ADM M7 (Vignati et al., 2004), which describes the aerosol distribution by 7 log-normal modes ( 4 soluble, 3 insoluble), was implemented as a submodel into the MESSy system. The boxmodel M7 was developed and is used by Stier et al. (2005) in ECHAM5-HAM. Emissions and loss processes of particles are not part of M7, but are calculated by other MESSy submodels (e.g. ONLEM, DRYDEP and SCAV). Thus we are using the same microphysical core as Stier et al. (2005), but source and sink processes are implemented differently. For example, $\mathrm{H}_{2} \mathrm{SO}_{4}$ is determined by the full chemical reaction mechanism as given by MECCA(-AERO), whereas Stier et al. (2005) calculate $\mathrm{H}_{2} \mathrm{SO}_{4}$ by the oxidation of DMS and $\mathrm{SO}_{2}$ by prescribed $\mathrm{OH}$.

M7 distinguishes five different aerosol components: sulphate (SU), black carbon (BC), soluble and insoluble 
Table 2. Distribution and characteristics of aerosol components in the M7 modes: $\mathrm{SU}=$ sulphate; OC=organic carbon; BC=black carbon; $\mathrm{SS}=$ sea salt; $\mathrm{DU}=$ dust.

\begin{tabular}{|c|c|c|c|c|c|c|c|}
\hline & Mode & SU & $\mathrm{OC}$ & $\mathrm{BC}$ & DU & SS & radius range $[\mu \mathrm{m}]$ \\
\hline 1 & nucleation soluble & $\mathrm{x}$ & & & & & $\bar{r} \leq 0.005$ \\
\hline 2 & Aitken soluble & $\mathrm{x}$ & $\mathrm{x}$ & $\mathrm{x}$ & & & $0.005<\bar{r} \leq 0.05$ \\
\hline 3 & accumulation soluble & $\mathrm{x}$ & $\mathrm{x}$ & $\mathrm{x}$ & $\mathrm{X}$ & $\mathrm{x}$ & $0.05<\bar{r} \leq 0.5$ \\
\hline 4 & coarse soluble & $\mathrm{x}$ & $\mathrm{x}$ & $\mathrm{x}$ & $\mathrm{x}$ & $\mathrm{x}$ & $0.5<\bar{r}$ \\
\hline 5 & Aitken insoluble & & $\mathrm{x}$ & $\mathrm{x}$ & & & $0.005<\bar{r} \leq 0.05$ \\
\hline 6 & accumulation insoluble & & & & $\mathrm{x}$ & & $0.05<\bar{r} \leq 0.5$ \\
\hline 7 & coarse insoluble & & & & $\mathrm{x}$ & & $0.5<\bar{r}$ \\
\hline
\end{tabular}

Table 3. Annually averaged primary emissions, dry deposition, sedimentation and wet deposition of $\mathrm{M} 7$ components. The units are $\mathrm{Tg}(\mathrm{S})$ for $\mathrm{SU}$ and $\mathrm{Tg}(\mathrm{C})$ for $\mathrm{OC}$ and $\mathrm{BC}$, respectively.

\begin{tabular}{lrrrrrr}
\hline component & $\begin{array}{r}\text { burden } \\
(\mathrm{Tg})\end{array}$ & $\begin{array}{r}\text { primary } \\
\text { lifetime } \\
\text { (days) }\end{array}$ & $\begin{array}{r}\text { dry } \\
(\mathrm{Tg} / \mathrm{yr})\end{array}$ & $\begin{array}{r}\text { reposition } \\
(\mathrm{Tg} / \mathrm{yr})\end{array}$ & $\begin{array}{r}\text { wet } \\
\text { sedimentation } \\
(\mathrm{Tg} / \mathrm{yr})\end{array}$ & $\begin{array}{r}\text { deposition } \\
(\mathrm{Tg} / \mathrm{yr})\end{array}$ \\
\hline SU & 0.4 & & 0.0 & 0.9 & 0.8 & 1.2 \\
OC & 1.0 & 4.1 & 88.0 & 6.0 & 3.6 & 66.2 \\
BC & 0.1 & 4.7 & 7.7 & 0.5 & 0.3 & 5.3 \\
DU & 5.6 & 3.7 & 554.2 & 34.6 & 112.3 & 275.8 \\
SS & 7.3 & 0.5 & 5213.3 & 1520.0 & 829.9 & 2774.1 \\
Accumulation & 0.1 & 0.6 & 56.3 & 3.8 & 0.1 & 11.1 \\
Coarse & 7.2 & 0.5 & 5157.0 & 1516.2 & 829.8 & 2763.0 \\
\hline
\end{tabular}

organic carbon (OC), sea salt (SS) and dust (DU). It distributes aerosol masses and particle numbers into 7 log-normal modes. Three of these modes contain only insoluble material (BC, OC and DU) and four modes are assumed to be internally mixed additionally containing soluble material (SU, OC and SS). Insoluble particles can be coated by sulphate, thus becoming soluble particles. Consequently, the larger soluble modes can contain all five components. Table 2 summarises the distribution of the different components among the modes and lists the corresponding dry radius ranges for the modes. The total particle number as well as the masses of the components of each mode are calculated prognostically, whereas the mean dry radius and the mean ambient radius are determined diagnostically. The radius standard deviation for each mode is kept constant ( $\sigma=2.0$ for the coarse modes and $\sigma=1.59$ for the other modes).

This modal structure requires 18 mass tracers and 7 number tracers, i.e. 25 aerosol tracers in total.

M7 simulates the following processes:

- Nucleation of sulphate particles, for which the mechanism by Vehkamäki et al. (2002) is applied.

- Condensation of $\mathrm{H}_{2} \mathrm{SO}_{4}$ onto all modes enabling the transfer of insoluble particle mass into soluble modes.

- Coagulation of aerosols.

- Transition from smaller to larger modes.
More details about the individual processes as simulated by M7 are given in Wilson et al. (2001), Vignati et al. (2004) and Stier et al. (2005).

\subsubsection{Emissions and removal processes}

Sea salt emissions are particularly important for the release of reactive bromine in the marine boundary layer. The scheme used for our simulation applies lookup tables. It is a wind speed dependent interpolation between the emission functions of Monahan (1986) and Smith and Harrison (1998). Since they depend on the aerosol mode definition, the lookup tables are especially designed for M7 emissions (Guelle et al., 2001; Schulz et al., 2004). Table 3 lists the annual primary emission fluxes for all M7 components. Primary emissions of sulphate are not taken into account in this model study. Furthermore, the budget of sulphate is rather low as we did not include volcanic emissions in our emission inventory, i.e. $\approx 12 \mathrm{Tg}(\mathrm{S}) / \mathrm{yr}$ are missing.

The organic and black carbon emissions used in this study have been adopted from the AeroCom B experiment (Dentener et al. (2006), http://nansen.ipsl.jussieu.fr/ AEROCOM/). They are subdivided into fossil fuel, biogenic fuel, wildfire emissions and Secondary Organic Aerosol (SOA) formation. 
The mineral dust emissions depend on the soil moisture, a source strength factor, a threshold velocity and the clay fraction of the uppermost soil layer (Balkanski et al., 2003). A more detailed description of all online calculated sources can be found in Kerkweg et al. (2006b). The Technical Note about MECCA-AERO (Kerkweg et al., 2007) contains a detailed description of the aerosol emissions and the aerosol removal processes (dry deposition, sedimentation and scavenging and wet deposition).

\subsection{The aerosol chemistry model}

In our model aerosol chemistry is explicitly calculated using the MESSy submodel MECCA-AERO (Kerkweg et al., 2007). MECCA-AERO uses the Kinetic PreProcessor (KPP, Damian et al. (2002), Sandu and Sander (2006)) to solve the differential equation set of the reaction mechanism. The reaction mechanism comprises 146 species reacting in 191 gas phase reactions, 65 photolysis reactions, and 10 heterogeneous reactions on polar stratospheric clouds. In the aqueous phase 13 acid-base equilibria, 24 phase transitions and 14 redox reactions are taken into account. In the supplement a complete list of all reactions included in the simulation is provided. All reactions and equilibria are explicitly calculated, hence the aerosol $\mathrm{pH}$ is also prognostically determined in this simulation. The $\mathrm{H}^{+}$concentration is treated like all other aerosol phase species concentrations, i.e. the $\mathrm{pH}$ is a direct result of the phase transitions and of the reactions in the aerosol phase. These themselves depend on the liquid water content (ambient radius), the abundance of the species in gas and aerosol phase and physical parameters such as temperature, pressure etc. Details on the determination of the rate coefficients are given in Kerkweg et al. (2007).

MECCA-AERO is affected by numerical instabilities araising from the extreme stiffness of the kinetic ODE (ordinary differential equation) system (see discussion in Kerkweg et al., 2007). Consequently, for this study explicit aerosol chemistry was calculated for only one aerosol mode. Since coarse mode sea salt aerosol is the dominant source of bromine, the physical information about the coarse mode of the ADM M7 is used in the present simulation. The solver was only stable when aerosol chemistry was limited to aerosols with a liquid water content larger than $10^{-12} \mathrm{~m}^{3}$ (aq) $/ \mathrm{m}^{3}$ (air). In the marine boundary layer the coarse mode aerosol water content is usually larger than this threshold, while it is smaller over land and in the free troposphere. Coarse mode sea salt aerosol is the most important source of atmospheric bromine, whereas the accumulation mode aerosol is important for the recycling of reactive bromine. Due to problems with the numerical instability we had to neglect the effect of the accumulation mode aerosol. Thus the amount of bromine released to the atmosphere by sea salt aerosol is expected to be well captured by our approach, whereas the partitioning between different gaseous substances, e.g. $\mathrm{BrNO}_{3}$ and $\mathrm{Br}_{2}$ is expected to be shifted towards $\mathrm{BrNO}_{3}$, as the recycling on the accumulation mode is missing. The effect of accumulation of bromine in very small particles (Sander et al., 2003) has not been captured by any model so far as the mechanism leading to this accumulation is not yet understood. In summary, the source of bromine through aerosol chemistry is expected to be realistic, while the recycling of bromine on the accumulation mode is ignored. Additionally the heterogeneous reactions (e.g. $\mathrm{HNO}_{3}$ uptake) are ignored in the free troposphere and over the continents where the aerosol water content is below $10^{-12} \mathrm{~m}^{3}$ (aq) $/ \mathrm{m}^{3}$ (air).

Near the surface the existence of very large particles may become important. The lifetime of these particles is very short as they sediment very fast because of their size. The grid boxes of the lowest model layer are higher than $60 \mathrm{~m}$. Since a value given for this box must be representative for the whole grid box, and since the large particles seldom reach a height of more than $10 \mathrm{~m}$, this effect of large particles is negligible in the model.

\section{Results and discussion}

\subsection{Aerosol distribution}

The distribution of sea salt aerosol strongly influences the release of bromine to the gas phase. Therefore its representation by M7 and the source and sink processes in MESSy are analysed in the following.

Figure 1 displays the annually averaged global sources and sinks. The panel on the upper left shows the sea salt emissions in $\mathrm{g} /\left(\mathrm{m}^{2} \mathrm{yr}\right)$. The largest emissions occur in the midlatitudes over the ocean, i.e. in the storm track regions. The high prevailing wind speeds lead to strong sea salt production. The smallest emissions over the ocean are found in the tropics west of the continents and throughout Polynesia.

Due to the short atmospheric lifetime of coarse mode sea salt particles (see Table 3), the spatial distribution of the sinks is highly correlated to the source distribution. The largest spatial gradients appear in the dry deposition process (upper right), showing the highest loss rate in the mid-latitudes and the lowest in the tropics. The storm track regions are associated with high wind speeds, hence the strongest dry deposition appears in these regions. The largest wet deposition events (lower right) occur also in the storm track regions, as wet deposition is strongest in regions where precipitation events are frequent. Although sedimentation (lower left) follows the same pattern as the other three processes, the gradient from the mid-latitudes to the tropics is relatively small. Since sedimentation only depends on the physical properties of the particles and on the density of the ambient air, the efficiency of sedimentation is not dependent on the wind speed in contrast to dry deposition. 

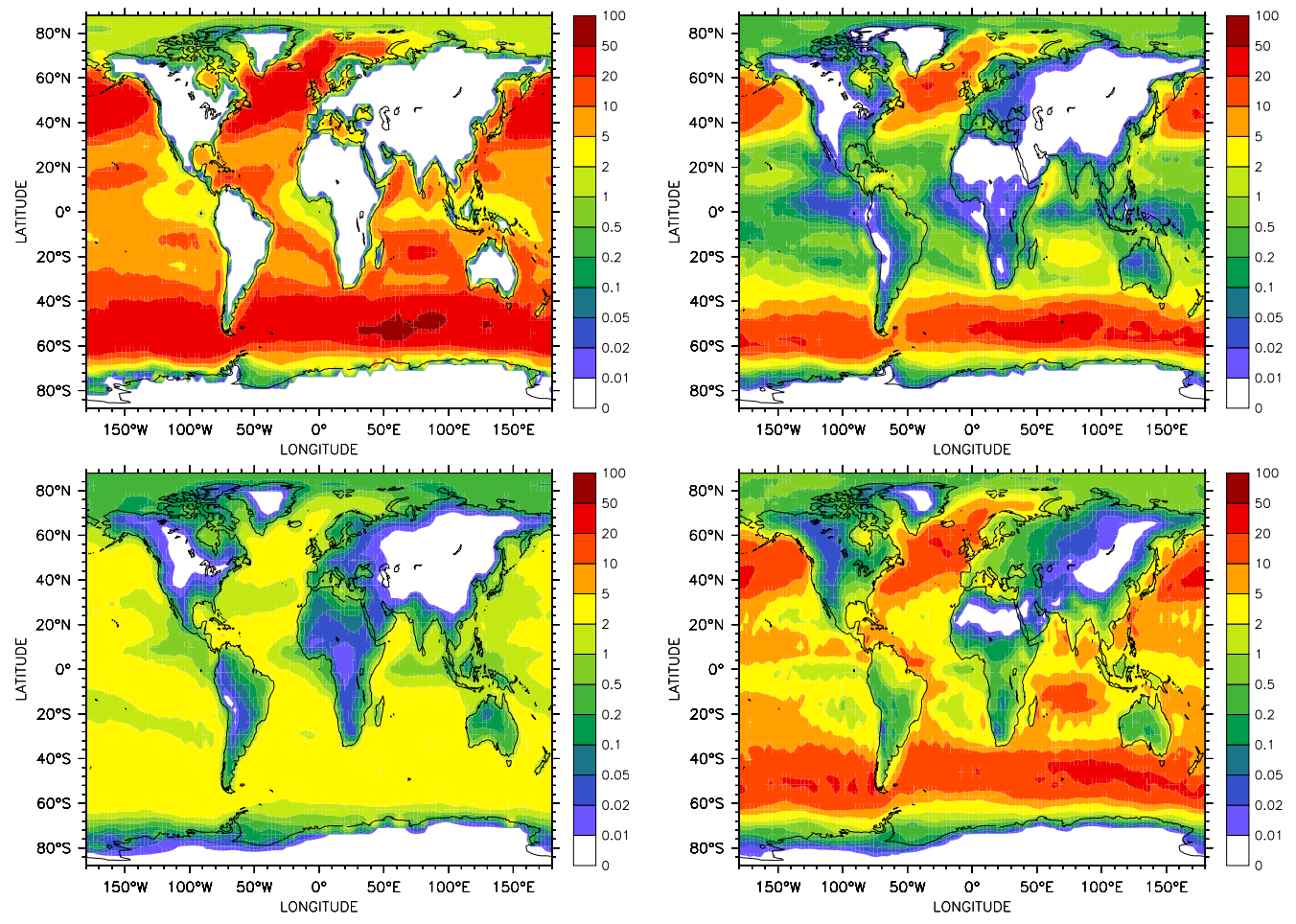

Fig. 1. Annually averaged sea salt sources and sinks $\left(\mathrm{g} /\left(\mathrm{m}^{2} \mathrm{yr}\right)\right)$ : top left: emission; top right: dry deposition (without gravitational settling); bottom left: sedimentation and bottom right: wet deposition.

Table 3 lists the annually integrated global source and sink fluxes for all M7 components in $\mathrm{Tg} / \mathrm{yr}$. The sulphate emissions are zero, because primary emissions are not taken into account. The largest and the smallest sink are wet deposition and sedimentation, respectively, except for dust for which the smallest sink is dry deposition. This is on the one hand in contrast to Pierce and Adams (2006) reporting dry deposition fluxes (including sedimentation) to be larger than wet deposition fluxes. On the other hand, Textor et al. (2006) state that "Models do neither agree on the split between wet and dry deposition, nor on that between sedimentation and other dry deposition processes.". Thus our results are similarly realistic than those of other aerosol dynamical models. A detailed analysis of the complete aerosol distribution simulated by this M7 implementation will be given in a follow-up paper. Here we only analyse the sea salt distribution which is important for the bromine release to the gas phase.

The simulated burden $(7.3 \mathrm{Tg})$ and the lifetime ( 0.5 days) of sea salt seem to be relatively low but they match the AeroCom median ( $7.5 \mathrm{Tg} / 0.5$ days) very well (Textor et al., 2006). Depending on the emission function, Pierce and Adams (2006) report sea salt burdens (lifetimes) ranging from 1.8 to $17.0 \mathrm{Tg}$ ( 0.46 to 2.72 days). In view of the burden our model is well within this range, but the lifetime is near the lower end. Differences in lifetime and in the vertical profiles between the measurements and the simulation have to be expected, as the simulated boundary layer comprises only $\approx 4$ layers on average, which makes it difficult to resolve boundary layer features as e.g. the capping inversion, which acts as a transport barrier and thus is essential for the vertical transport of emitted species. Only a few measured vertical profiles exist (Maring et al., 2003) showing a rapid decrease with height. These gradients are much smaller in the simulation (not shown here). Sea salt captured in the boundary layer is much less subject to wet removal processes, as clouds often form above the boundary layer. This might be a reason for the relatively short lifetime simulated by the model.

Stier et al. (2005) report a burden/lifetime of $10.5 \mathrm{Tg} / 0.8$ days. The differences between the burdens/lifetimes of Stier et al. (2005) and our simulation are also apparent when comparing the annually averaged vertically integrated column mass (their Fig. 2 to our Fig. 2). ECHAM5-HAM predicts values between 20 and $50 \mathrm{mg} / \mathrm{m}^{2}$ in most oceanic regions, exceeded by some regions where concentrations between 50 and $100 \mathrm{mg} / \mathrm{m}^{2}$ occur. In $\mathrm{E} 5 / \mathrm{M}^{+}$results range from 10 to $50 \mathrm{mg} / \mathrm{m}^{2}$ over the ocean. However, the patterns of the distribution are very similar. Since ECHAM5-HAM and E5/M1+ use the same microphysical core of the aerosol model and the same sea salt emission function these differences are caused by more efficient sink processes in $\mathrm{E} 5 / \mathrm{M} 1^{+}$. Here, especially the treatment of the wet deposition as the dominant sink is 


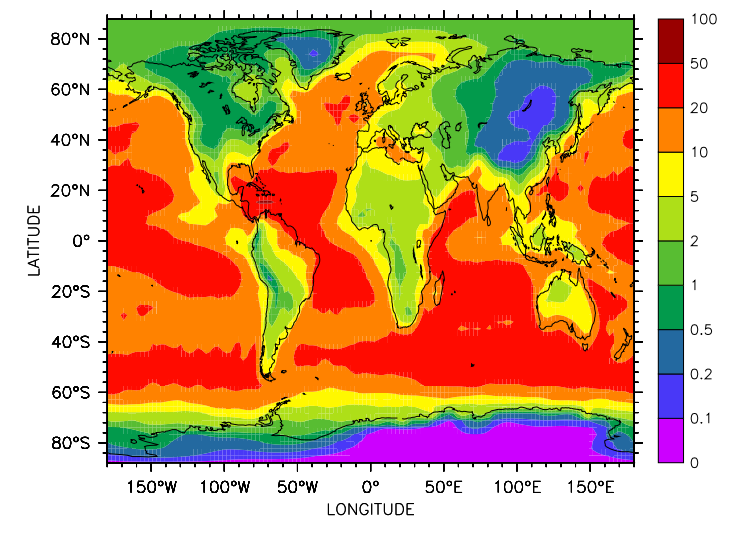

Fig. 2. Annually averaged vertically integrated atmospheric sea salt column mass $\left(\mathrm{mg} / \mathrm{m}^{2}\right)$.

important. Since the MESSy implementation describes the process in more detail, differences in the efficiency of this process are expected. The implementation in MESSy leads to a higher loss rate which might be true or overestimated. Since the sea salt lifetime has only been crudely estimated so far, the shorter sea salt lifetimes in our simulation and in the AeroCom median may be closer to reality as an often used assumption for the lifetime of coarse mode sea salt of 2 days (Sander and Crutzen, 1996). The lifetime influences the aerosol pH especially in regions with low gas phase acid concentrations. Hence the time available for acidification of the aerosol is significantly longer in models using the assumption of a sea salt lifetime of 2 days.

It is rather difficult to compare simulation results to measurements and this is even harder for a relatively coarse model resolution. Measurements are mostly taken at single, distinct locations, whereas the model grid box represents approximately $250 \mathrm{~km} \times 250 \mathrm{~km}$ and averages over this area. Nevertheless, some comparisons are presented here. Most data are obtained during measurement campaigns limited to a specific region and to a time frame of a few weeks. Measurements are limited by the inlet properties (e.g. strong winds normally lead to loss of sea salt), thus the measured mass is most likely - but not substantially - underestimated.

Lewis and Schwartz (2004) review measurements and model results related to sea salt. Their Fig. 17 displays measurements of sea salt aerosol mass concentrations as a function of the $10 \mathrm{~m}$ wind speed. Most of the measurements are in the range of 5 to $100 \mu \mathrm{g} / \mathrm{m}^{3}$, and the simulated sea salt mass concentrations of our study shown in Fig. 3 correspond well to the extent that the data sets are comparable. Phinney et al. (2006) report a mean mass concentration of $2.4 \mu \mathrm{g} / \mathrm{m}^{3}$ for the north east Pacific Ocean. This is substantially lower than in our model which predicts values between 5 and $20 \mu \mathrm{g} / \mathrm{m}^{3}$. Fitzgerald (1991) reports in his review typical concentrations between 2 and $50 \mu \mathrm{g} / \mathrm{m}^{3}$ for coarse mode aerosol over the remote ocean, which matches our simulation.

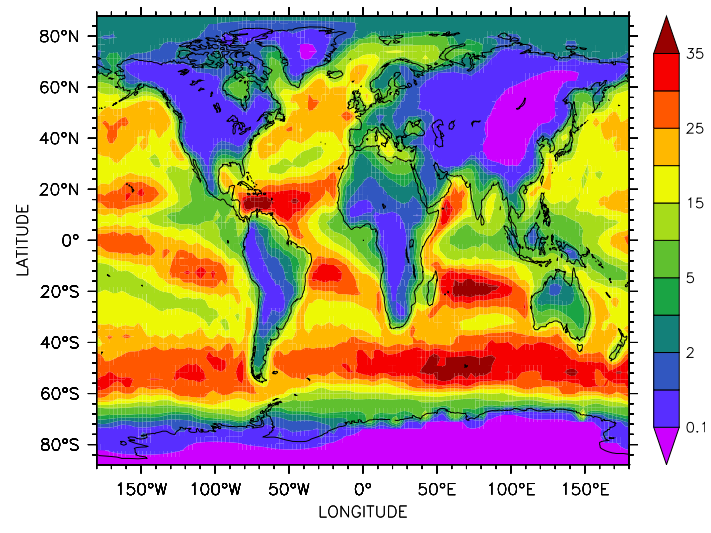

Fig. 3. Annually averaged (coarse mode) sea salt aerosol concentration $\left(\mu \mathrm{g} / \mathrm{m}^{3}\right)$ in the lowest model layer. The lowest model layer is between 52 and 70 ( 65 on average) $\mathrm{m}$ thick.

Many aerosol measurements are made available by AeroCom (http://nansen.ipsl.jussieu.fr/AEROCOM/).

Here we focus on five projects in which sea salt aerosol concentrations have been measured: the IMPROVE network (http://vista.cira.colostate.edu/improve/Data/IMPROVE/ improve_data.htm), the EMEP network

(http://www.emep.int/index_data.html), and the AEROCE, DOE-EML and SEAREX measurement stations (J. Prospero, personal communication; for some information about the individual programs see e.g. http://www.igac.noaa.gov/newsletter/24/aeroce.php or Duce, 1982).

At the continental locations in North America (IMPROVE network) and Europe (EMEP) our sea salt concentrations are consistently much higher than those observed (not shown here). This behaviour is to be expected, as the sea salt concentrations are mostly infered from measured sodium concentrations which are not conservative in continental air. In addition, the transport of coarse mode particles is overestimated in the model because of its coarse model resolution.

Thus the remaining data for the comparison are the AEROCE/SEAREX/DOE-EML data, mostly comprising stations located at the coast or on islands. Table 4 lists the individual stations, their locations and the program under which they are operated. In the data set used for the comparison sea salt mass concentrations $c_{s s}$ have been estimated from the measured sodium concentrations $c_{\mathrm{Na}}$ by assuming $c_{s s}=c_{\mathrm{Na}} / 0.3071$.

Figure 4 depicts the AEROCE/SEAREX/DOE-EML stations ordered from north to south. Shown are the climatological monthly arithmetic average values for the measurements and monthly arithmetic averages for the year 2000 for the simulation. The averaged sea salt concentration tends to be underestimated for the two northernmost stations Heimaey and Mace Head. But the simulated average is well within the uncertainties of the measurements. For the stations located 

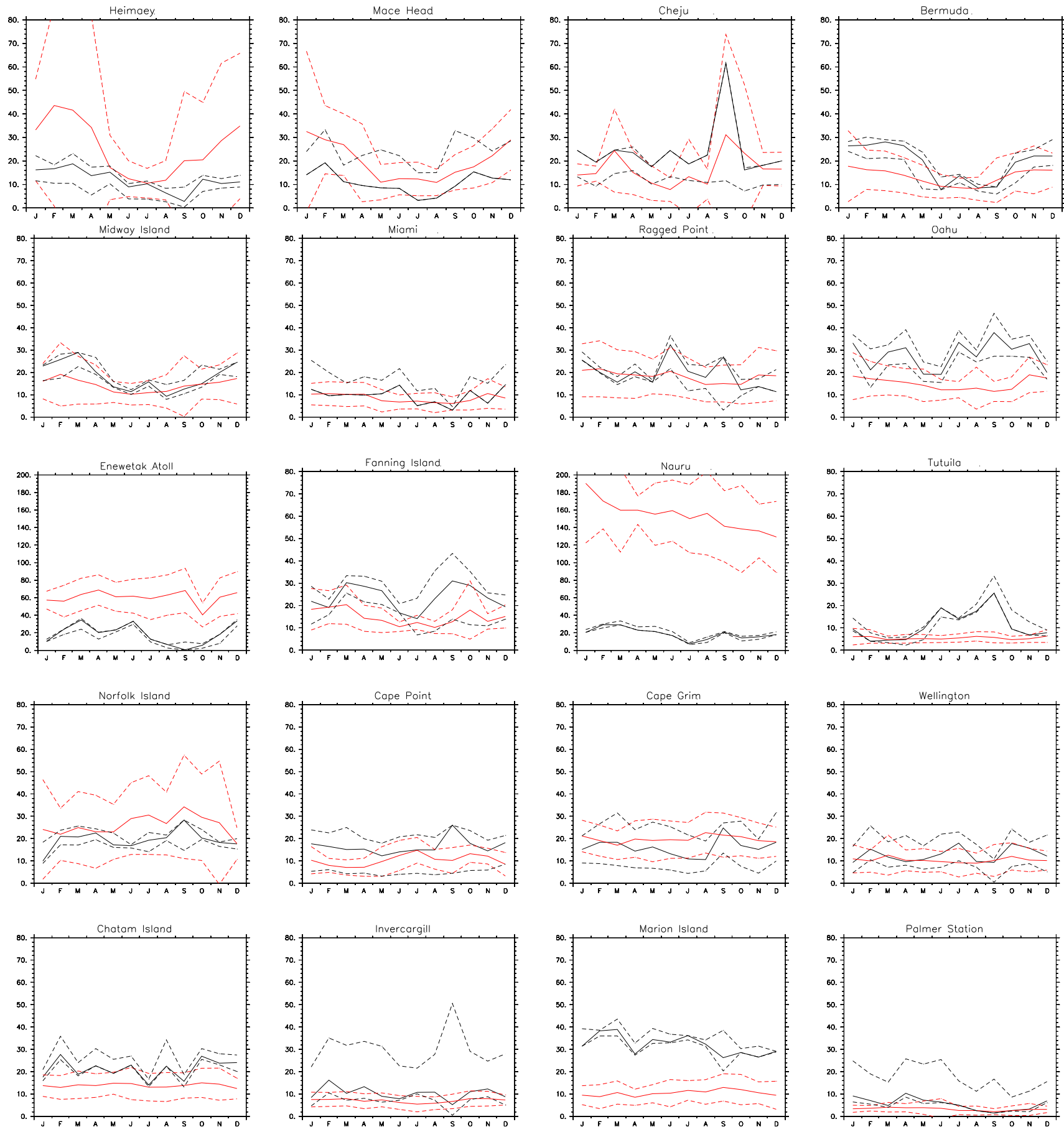

Fig. 4. Comparison of observed (AEROCE/SEAREX/DOE-EML measurements,red) and simulated (black) sea salt mass concentrations $\left(\mu \mathrm{g} / \mathrm{m}^{3}\right)$. The measurements are climatological monthly arithmetic averages over the period listed in Table 4 . The simulation results are calculated monthly arithmetic averages for the year 2000 based on the 5-hourly output. The stations are sorted from north to south. The dashed lines illustrate the uncertainties, i.e. for the measurements the $1 \sigma$ standard deviation and for the model the minimum and the maximum of the monthly average for the circumjactent grid-boxes. 
Table 4. AEROCE/SEAREX/DOE-EML aerosol measurement stations. Listed are the location of the stations, the program operating the station and the start and end month of operation.

\begin{tabular}{|c|c|c|c|c|c|}
\hline Station & latitude & longitude & Program & start & end \\
\hline Heimaey & $63.442^{\circ} \mathrm{N}$ & $20.25^{\circ} \mathrm{W}$ & AEROCE & Jul 1991 & Jan 1998 \\
\hline Mace Head & $53.19^{\circ} \mathrm{N}$ & $9.54^{\circ} \mathrm{W}$ & AEROCE & Aug 1988 & Aug 1994 \\
\hline Cheju (Kosan) & $33.37^{\circ} \mathrm{N}$ & $126.53^{\circ} \mathrm{E}$ & SEAREX & Sep 1991 & Oct 1995 \\
\hline Bermuda & $32.33^{\circ} \mathrm{N}$ & $64.75^{\circ} \mathrm{W}$ & AEROCE & Mar 1989 & Jan 1998 \\
\hline Midway Island & $28.2^{\circ} \mathrm{N}$ & $177.37^{\circ} \mathrm{W}$ & SEAREX & Jan 1981 & Jan 1997 \\
\hline Miami & $25.78^{\circ} \mathrm{N}$ & $80.22^{\circ} \mathrm{W}$ & AEROCE & Jan 1989 & Aug 1998 \\
\hline Ragged Point & $22.22^{\circ} \mathrm{N}$ & $75.73^{\circ} \mathrm{W}$ & AEROCE & May 1984 & Jul 1998 \\
\hline Oahu & $21.47^{\circ} \mathrm{N}$ & $157.98^{\circ} \mathrm{W}$ & SEAREX & Jan 1981 & Jul 1995 \\
\hline Enewetak Atoll & $11.5^{\circ} \mathrm{N}$ & $162.33^{\circ} \mathrm{E}$ & SEAREX & Feb 1981 & Jun 1987 \\
\hline Fanning Island & $3.86^{\circ} \mathrm{N}$ & $159.36^{\circ} \mathrm{W}$ & SEAREX & Apr 1981 & Aug 1986 \\
\hline Nauru & $0.53^{\circ} \mathrm{S}$ & $166.94^{\circ} \mathrm{E}$ & SEAREX & Mar 1983 & Oct 1987 \\
\hline Tutuila & $14.29^{\circ} \mathrm{S}$ & $170.72^{\circ} \mathrm{W}$ & SEAREX & Mar 1983 & Jan 1996 \\
\hline Norfolk Island & $29.03^{\circ} \mathrm{S}$ & $167.95^{\circ} \mathrm{E}$ & SEAREX & May 1983 & Feb 1997 \\
\hline Cape Point & $33.95^{\circ} \mathrm{S}$ & $18.41^{\circ} \mathrm{E}$ & DOE-EML & Feb 1992 & Nov 1996 \\
\hline Cape Grim & $41^{\circ} \mathrm{S}$ & $145^{\circ} \mathrm{E}$ & DOE-EML & Jan 1983 & Nov 1996 \\
\hline Wellington & $41.28^{\circ} \mathrm{S}$ & $174.77^{\circ} \mathrm{E}$ & DOE-EML & Oct 1987 & Nov 1996 \\
\hline Chatam Island & $43.9^{\circ} \mathrm{S}$ & $176.49^{\circ} \mathrm{W}$ & DOE-EML & Sep 1983 & Oct 1996 \\
\hline Invercargill & $46.40^{\circ} \mathrm{S}$ & $168.35^{\circ} \mathrm{E}$ & DOE-EML & Jun 1983 & Nov 1996 \\
\hline Marion Island & $46.77^{\circ} \mathrm{S}$ & $37.85^{\circ} \mathrm{E}$ & DOE-EML & Mar 1992 & May 1996 \\
\hline Palmer Station & $64.76^{\circ} \mathrm{S}$ & $64.05^{\circ} \mathrm{W}$ & DOE-EML & Apr 1990 & Oct 1996 \\
\hline
\end{tabular}

around $30^{\circ} \mathrm{N}$ (Cherju, Bermuda, Midway Island) the simulation is at the high end but reproduces the sea salt abundance and the annual cycle. At low latitudes (Miami, Ragged Point, Oahu) the simulation overestimates both, the variability and the abundance. For Miami and Ragged Point no systematic deviations are apparent, whereas the sea salt abundance in Oahu is overestimated. For the western Pacific stations, Enewetak Atoll and Nauru, the simulation strongly underestimates the sea salt abundance, whereas for the stations in the eastern Pacific, Fanning Island and Tutuila, it overestimates it, but the difference is less pronounced. Both effects might be attributed to local effects which are not included in the global model. For the southern hemispheric mid-latitude stations Norfolk Island, Cape Point, Cape Grim and Wellington the simulation reproduces the measurements very well within the uncertainties. At the four southern-most stations Chatam Island, Invercargill, Marion Island and Palmer Station, the model substantially overestimates the sea salt abundance.

To summarise, the model tends to overestimate the sea salt concentrations over the continents. This is on the one hand related to the coarse resolution of the model. On the other hand the sea salt mass concentrations are mostly inferred from sodium measurements and sodium is not conservative over the continents, which inevitably leads to deviations between the measurements and the simulation. Over the oceans the picture is not as clear. Often local effects which cannot be resolved within a global model seem to determine the measured sea salt mass. In addition, the simulated "surface" con- centrations represent an average for a box $250 \mathrm{~km} \times 250 \mathrm{~km}$ wide and $\approx 65 \mathrm{~m}$ high. But the measurement at the coast are mostly taken below the average box height of $32.5 \mathrm{~m}$.

Number concentrations of coarse mode aerosol are reported more often than sea salt masses. Table 5 lists the measurements discussed below. Large particles form by primary emissions of sea salt and dust, and by growth of smaller particles, e.g. by sulphate condensation, by coagulation or by evaporation of cloud droplets. Consequently, in the representation of the submodel M7 these particles consist not only of sea salt and dust, but also of organic matter, black carbon and sulphate. Unfortunately M7 does not take nitrate into account, which is often found as a major constituent in aged aerosol particles. The growth of smaller particles into the accumulation mode mainly determines the particle number in this size range, yielding relatively high numbers. However, the number concentration of coarse mode particles is mainly driven by primary emissions. Additionally processing of aerosols by clouds leads to the formation of large aerosol particles.

Figure 5 shows the simulated annually averaged number concentration of the coarse mode aerosol. In case of cloud evaporation all resulting aerosol particles are put into the coarse mode by the submodel SCAV. As sulphate emissions are high over europe, the large maximum in this region is most probably an artefact of this parameterisation.

Lewis and Schwartz (2004) report number concentrations ranging from below $1 \mathrm{~cm}^{-3}$ up to a maximum of $200 \mathrm{~cm}^{-3}$. This is in good correspondence with the 
Table 5. Measurements of aerosol number concentrations.

\begin{tabular}{llll}
\hline Reference & Location & concentration $\left(1 / \mathrm{cm}^{3}\right)$ & radius $(\mu \mathrm{m})$ \\
\hline Lewis and Schwartz (2004) & global & $1-20$ (up to 200) & \\
O'Dowd and Smith (1993) & north-east Atlantic & $2-80$ & $0.005<r<1.5$ \\
& & $5-10$ & $0.3<r<1.5$ \\
Bates et al. (1998) & Southern Ocean & clean: 15 & $\mathrm{r}>0.15$ \\
& & continentally infl. 23 & $\mathrm{r}>0.15$ \\
Murphy et al. (1998) & Southern Ocean & 30 & $\mathrm{r}>0.16$ \\
Guazzotti et al. (2001) & Indian Ocean & $<1-5$ & $0.1<r<1.25$ \\
\hline
\end{tabular}

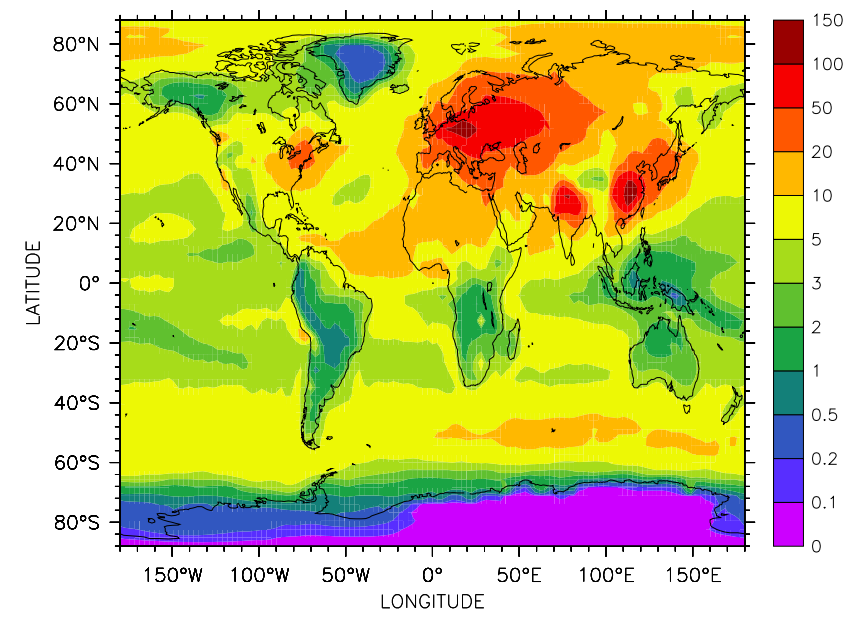

Fig. 5. Annually averaged coarse mode particle concentration $\left(\mathrm{cm}^{-3}\right)$ in the lowest model layer.

simulated number concentrations. Most of the oceanic measurements reviewed by Lewis and Schwartz (2004) are between $1 \mathrm{~cm}^{-3}$ and $20 \mathrm{~cm}^{-3}$, which agrees also well with the annual average number concentrations in our simulation.

An additional difficulty in comparing field data with model results is that most of the time the measured and the simulated radii intervals do not exactly match. Furthermore, the measurements are associated with some uncertainties. For example, a trend seems to be evident with smaller number concentrations reported in the literature in the early studies increasing to larger ones in more recent studies. Small numbers were reported in the 1970s and 1980s from $<1 \mathrm{~cm}^{-3}$ up to $10 \mathrm{~cm}^{-3}$ as an upper limit (for details see Lewis and Schwartz, 2004). More recent studies presented higher number concentrations. O'Dowd and Smith (1993) measured concentrations in the range of $2 \mathrm{~cm}^{-3}$ to $80 \mathrm{~cm}^{-3}$ in OctoberNovember 1989 over the north-east Atlantic for sea salt aerosol diameters ranging from $0.01 \mu \mathrm{m}$ to $3 \mu \mathrm{m}$. Hence, the measured number concentrations correspond to the sum of the number concentrations of the coarse and the accumu-

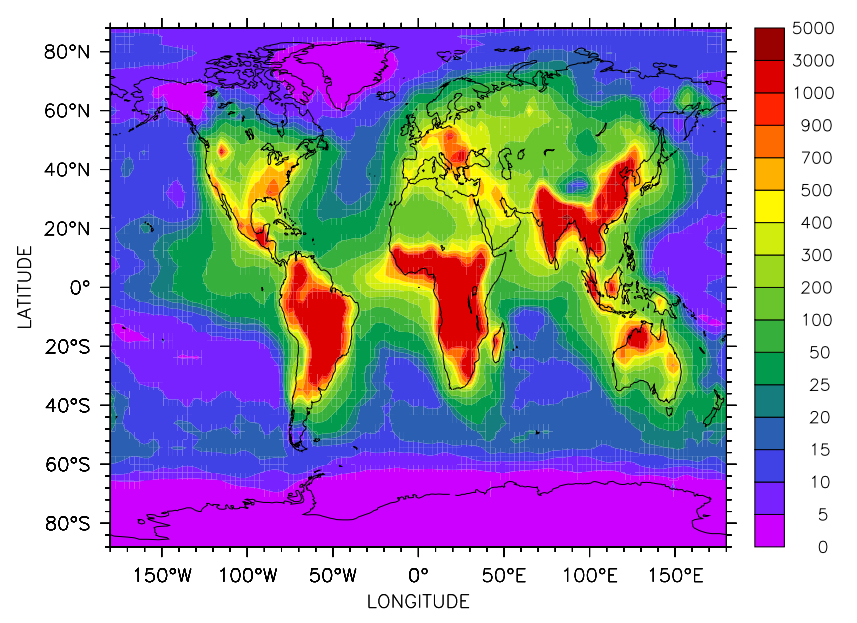

Fig. 6. Annually averaged accumulation and coarse mode particle concentration $\left(\mathrm{cm}^{-3}\right)$ in the lowest model layer.

lation mode. Figure 6 shows the seasonally averaged sum of the number concentrations of the accumulation and the coarse modes. These number concentrations closely correspond to the observations. From the figures shown by O'Dowd and Smith (1993), a mean particle number concentration for coarse mode aerosol (diameter $0.6 \mu \mathrm{m}-3 \mu \mathrm{m}$ ) of around $5 \mathrm{~cm}^{-3}-10 \mathrm{~cm}^{-3}$ can be deduced. For the northeastern Atlantic our model predicts concentrations between $1 \mathrm{~cm}^{-3}$ and $5 \mathrm{~cm}^{-3}$, thus slightly lower than the observations. Bates et al. (1998) and Murphy et al. (1998) both published measurements from ACE 1 (the First Aerosol Characterisation Experiment). ACE 1 took place from 15 November to 14 December 1995, in a region south-south-east of Tasmania, Australia in the Southern Ocean. Even though taking part in the same campaign they report different results. Bates et al. (1998) measured number concentrations of about $15 \mathrm{~cm}^{-3}$ in clean marine air and $23 \mathrm{~cm}^{-3}$ in continentally influenced air for particles larger than $0.3 \mu \mathrm{m}$ in diameter. Murphy et al. (1998) report concentrations of $30 \mathrm{~cm}^{-3}$ for particles larger than $0.16 \mu \mathrm{m}$ in diameter. Both 


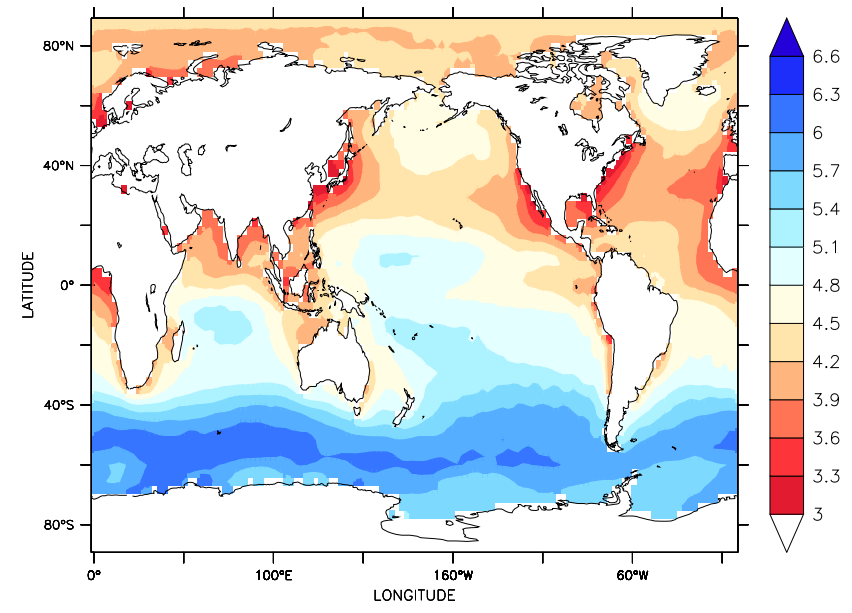

Fig. 7. Annually averaged boundary layer coarse mode aerosol $\mathrm{pH}$ for the year 2000 .

particle ranges include parts of the M7 accumulation mode. Thus, since Fig. 5 shows smaller concentrations for coarse mode aerosol only and Fig. 6 larger values for the sum of accumulation and coarse mode particles, our simulation results agree with the range of the measurements. Guazzotti et al. (2001) measured aerosols during the Indian Ocean Experiment from February to March 1999 and observed a range from less than $1 \mathrm{~cm}^{-3}$ to $5 \mathrm{~cm}^{-3}$. The model simulates number concentrations between $1 \mathrm{~cm}^{-3}$ to $10 \mathrm{~cm}^{-3}$, i.e. slightly higher than the measurements.

To summarise, the model is in reasonable agreement with the reported measurements taking into account the model's limitations and the uncertainties of the observations. The model tends to slightly overestimate the mass and to slightly underestimate the number concentrations of sea salt aerosol.

\subsection{Coarse mode aerosol $\mathrm{pH}$}

The aerosol $\mathrm{pH}$ is a key driver of aerosol chemistry. Keene et al. (1998) point out its importance for sulphate oxidation and for dehalogenation: at $\mathrm{pH} 8$ the reaction of sulphur(IV) with ozone is dominant, at $\mathrm{pH} 5.5$ oxidation by $\mathrm{HOCl}$ and $\mathrm{H}_{2} \mathrm{O}_{2}$ prevails, and at $\mathrm{pH} 3$ the decreased effective $\mathrm{SO}_{2}$ solubility slows down the oxidation to sulphur(VI). The amount of $\mathrm{HCl}$ release changes drastically between $\mathrm{pH} 5.5$ and 3, whereas the release of bromine is relatively constant and very efficient in this $\mathrm{pH}$ range. For aerosols containing chlorine the $\mathrm{HCl} / \mathrm{Cl}^{-}$buffer is important for the aerosol $\mathrm{pH}$ (Fridlind and Jacobson, 2000; Keene and Savoie, 1998).

The aerosol $\mathrm{pH}$ is rather difficult to measure. Only a few direct measurements of diluted aerosol samples exist (Keene et al., 2002, 2004). In most cases the aerosol pH - if reported at all - is estimated by assuming the aerosol to be in thermodynamic equilibrium (Keene et al., 1998; Fridlind and Jacobson, 2000). Based on this assumption an aerosol $\mathrm{pH}$ for each acid measured in gas and aqueous phase can be calculated. The disadvantage of this method is that the calculated $\mathrm{pH}$ depends on the respective acid (Keene et al., 2004), as for each acid individual assumptions with individual errors (e.g. for the Henry's law coefficient) must be made. Thus the calculated $\mathrm{pH}$-values for different acids in the same dilution diverge. Another approach is to include all measured concentrations in an equilibrium (box-)model for the calculation of a single mean pH-value. Fridlind and Jacobson (2000) used the thermodynamic equilibrium model EQUISOLVII for this purpose. But the assumption of thermodynamic equilibrium is a simplification.

Keene et al. (2004) state that phase disequilibria can cause positive and negative deviations in median $\mathrm{pH}$-values. They observed negative phase disequilibria in their measurements of sea salt only to occur for aerosol particle diameters larger than $2.8 \mu \mathrm{m}$. Unfortunately, because of these difficulties in measuring aerosol $\mathrm{pH}$, only few measurements are available. They are shown in Table 6.

Here a comparison of simulated and measured/inferred aerosol $\mathrm{pH}$-values is provided. In this comparison it has to be taken into account that the chemical mechanism applied in this study does not include organic acids. Organic acids contribute substantially to the acidification of sea salt aerosol over the remote ocean (Keene and Galloway, 1986). Thus the simulated $\mathrm{pH}$-values over the remote ocean have to be regarded as upper limits.

Figure 7 shows the simulated annual average aerosol $\mathrm{pH}$ in the marine boundary layer (MBL). Since the $\mathrm{pH}$ is defined as the logarithm of the $\mathrm{H}^{+}$concentration, it is not straight forward to calculate spatial and/or temporal average $\mathrm{pH}$-values. One method is to average the $\mathrm{H}^{+}$concentrations and calculate the logarithm. This method has the disadvantage that one single event with a very low $\mathrm{pH}$ dominates the average because of the logarithmic scale of the $\mathrm{pH}$-value. For this reason we decided to average the $\mathrm{pH}$-values directly, which much better represents the typical $\mathrm{pH}$-values of a specific region or period. Due to numerical reasons the aerosol chemistry was only calculated when the liquid water content was above $10^{-12} \mathrm{~m}^{3} / \mathrm{m}^{3}$. Consequently, the $\mathrm{pH}$-calculation is in fact - restricted to the lowest five model layers, which is well above the simulated MBL height. The diagnosed MBL height ranges from 100 to $2000 \mathrm{~m}$ a.s.l. The annual average reaches from 400 to $800 \mathrm{~m}$ (see Fig. "mbl_height.pdf" in the supplement).

In general the $\mathrm{pH}$ is lower in the Northern Hemisphere. This is a direct consequence of the higher abundance of acids in the Northern Hemisphere where the largest emissions of acid precursors take place, e.g. in large urban areas, by power-plants and industries. The highest $\mathrm{pH}$-values are reached in the southern ocean storm track - the dominant source region for sea salt aerosol. Freshly emitted sea salt aerosol is alkaline and the abundance of gas phase 
Table 6. List of publications about measured or inferred coarse mode aerosol $\mathrm{pH}$.

\begin{tabular}{llllll}
\hline & $\mathrm{pH}$ & location & & time & reference \\
\hline $\mathrm{A}$ & $3.5-4.5$ & Bermuda & $32^{\circ} \mathrm{N}, 64^{\circ} \mathrm{W}$ & April-May 1996 & Keene and Savoie (1999) \\
$\mathrm{B}$ & $2-5$ & Southern ocean & $40^{\circ}-55^{\circ} \mathrm{S}, 60^{\circ}-135^{\circ} \mathrm{E}$ & $18 \mathrm{Nov}-11 \mathrm{Dec} 1995$ & Fridlind and Jacobson (2000) \\
$\mathrm{C}$ & $3.3-5.3$ & Bermuda & $32^{\circ} \mathrm{N}, 64^{\circ} \mathrm{W}$ & 2-27 May 1997 & Keene et al. (2002) \\
$\mathrm{D}$ & $4.5-5.4$ & Hawaii & $21^{\circ} \mathrm{N}, 157^{\circ} \mathrm{W}$ & 4-29 September 1999 & Pszenny et al. (2004) \\
$\mathrm{E}$ & $1.9-3.3$ & US east coast & & July-August 2002 & Keene et al. (2004) \\
\hline
\end{tabular}
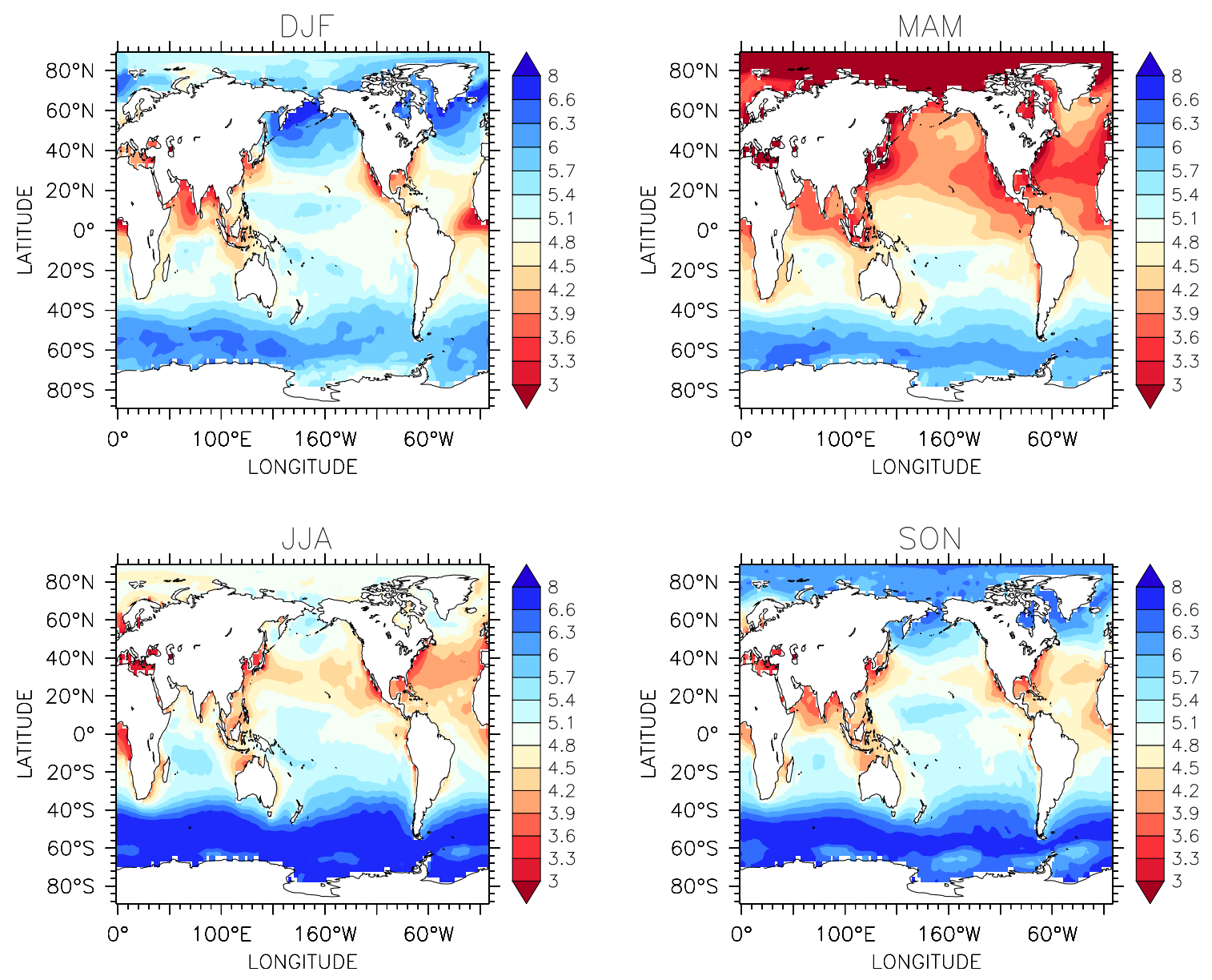

Fig. 8. Seasonally averaged boundary layer sea salt aerosol pH. (DJF: December, January, February; MAM: March, April, May; JJA: June, July, August; SON: September, October, November).

acids is relatively low in the Southern Hemisphere; thus the southern storm tracks stand out because of high aerosol $\mathrm{pH}$. The source of alkalinity is not much smaller in the northern storm tracks, but there titration by acids reduces the $\mathrm{pH}$. The difference between the southern and the northern hemispheric storm tracks might be overestimated in this simulation because of the neglection of organic acids, which leads to an underestimation of the acidification of the aerosol in remote regions. Not surprisingly, the outflow regions of the continents show the lowest $\mathrm{pH}$-values.
The seasonal differences of the aerosol $\mathrm{pH}$ are shown in Fig. 8. The aerosol in both hemispheres is more strongly acidified by approximately $2 \mathrm{pH}$ units in the respective spring/summer than in the winter season. In spring/summer surface winds are weaker leading to less efficient exchange processes (sources as well as sinks) and consequently to a longer residence time for the aerosol resulting in higher acidification. In the southern hemispheric winter strong emissions in the southern ocean storm tracks and the lower abundance of inorganic gas phase acids lead to slightly 

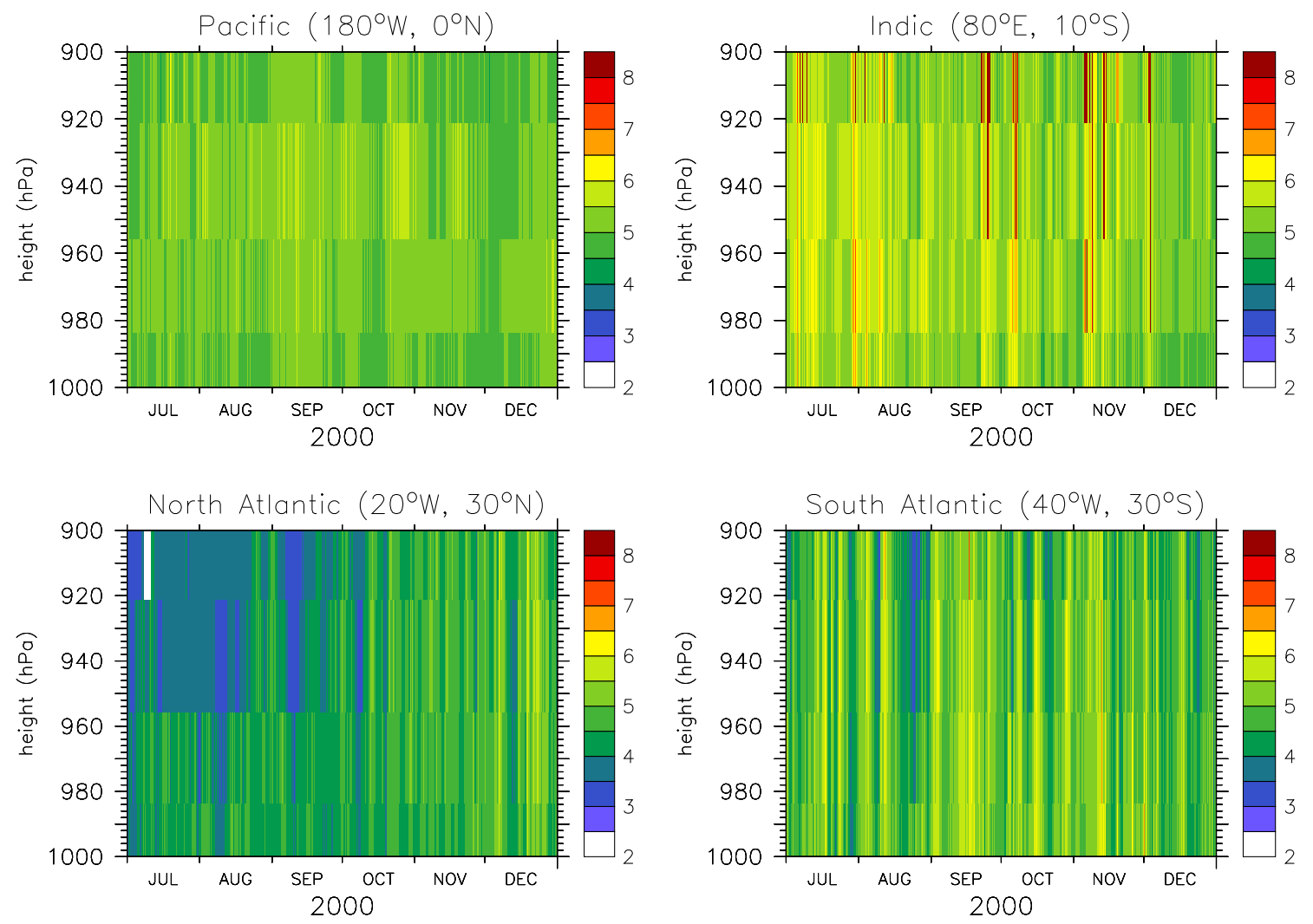

Fig. 9. Vertical and temporal variability of coarse mode aerosol $\mathrm{pH}$ at four distinct locations over the remote oceans.

alkaline $(\mathrm{pH} \approx 8)$ aerosol. In contrast, the aerosol is slightly acidified $(\mathrm{pH} \approx 6)$ in the same region in summer. In the Northern Hemisphere the aerosol is acidified throughout the year reaching $\mathrm{pH}$-values as low as 4 in spring and up to 6 in winter.

Averages of $\mathrm{pH}$-values, however, do not provide the full picture. To give more insight into the temporal variability and the vertical structure of the aerosol pH, Fig. 9 shows the instantaneous $\mathrm{pH}$-values at 4 arbitrarily chosen locations over the remote oceans. Most of the time the $\mathrm{pH}$-values fluctuate not more than one $\mathrm{pH}$-unit within one output interval (i.e. $5 \mathrm{~h}$ ). No distinct vertical profiles are present. This is in contrast to the results published by von Glasow et al. (2002) reporting a pH-decrease from the sea surface up to the boundary layer top. This difference is most probably due to the differences between a global and a column model. The global model has to resolve the boundary layer with $\approx 4$ vertical layers. This coarse resolution can cause these differences. The vertical structure of the aerosol $\mathrm{pH}$ and its dependence on the liquid water content will be discussed in broader detail in the third part of this article series investigating the release of halogens from the aerosol which is strongly $\mathrm{pH}$ dependent.
As averages of $\mathrm{pH}$-values are not fully representative we also show frequency distributions of $\mathrm{pH}$-values. The histograms are scaled with the number of events and normalised to $100 \%$.

Figures 10 and 11 show frequency distributions of the $\mathrm{pH}$ at two distinct locations for four selected months to visualise the seasonal cycle of sea salt aerosol $\mathrm{pH}$ and the frequency of occurrence of particular $\mathrm{pH}$-values. The first gridbox $\left(170^{\circ} \mathrm{W}, 55^{\circ} \mathrm{N}\right)$ is located in the middle of the North Atlantic ocean. This region is influenced by the outflow of North America. This leads to relatively low $\mathrm{pH}$-values and little variation in the $\mathrm{pH}$ distribution throughout the year. The lowest $\mathrm{pH}$-values occur in March, where the sea salt $\mathrm{pH}$ is 4 or less most of the time. The highest $\mathrm{pH}$-values occur in December. At this time of the year the wind speed and sea salt emissions are strongest leading to a stronger alkalinity source.

The second series of frequency distributions (Fig. 11) refers to the southern ocean storm track region $\left(100^{\circ} \mathrm{E}\right.$, $50^{\circ} \mathrm{S}$ ). In the southern hemispheric winter (June to October) the aerosol is neutral (almost alkaline). The aerosol is slightly acidified throughout the rest of the year with lowest values (of around 5) in the southern hemispheric autumn. 


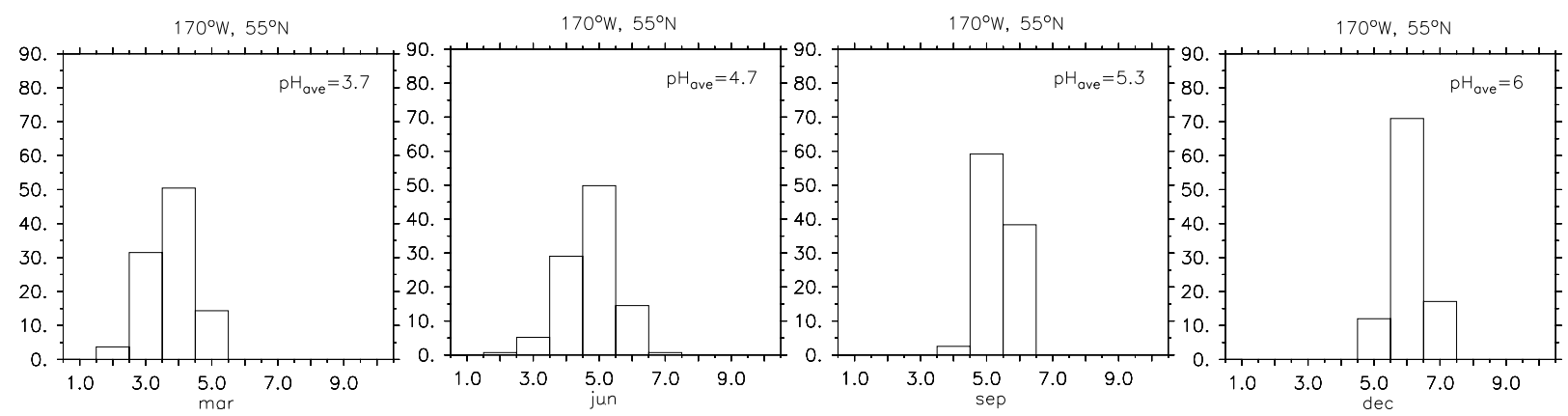

Fig. 10. Probability density functions (PDF, normalised to 100\%) of simulated boundary layer pH-values at $170^{\circ} \mathrm{W}, 55^{\circ} \mathrm{N}$ for $\mathrm{March}$, June, September and December of the year 2000.
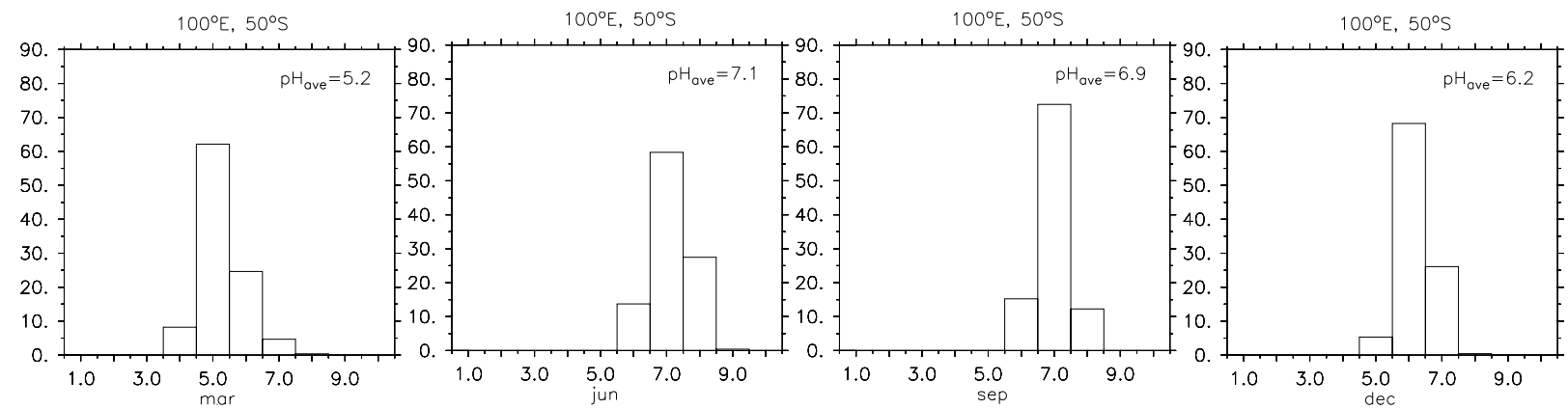

Fig. 11. As Fig. 10: PDFs of simulated boundary layer pH-values at $100^{\circ} \mathrm{E}, 50^{\circ} \mathrm{S}$.
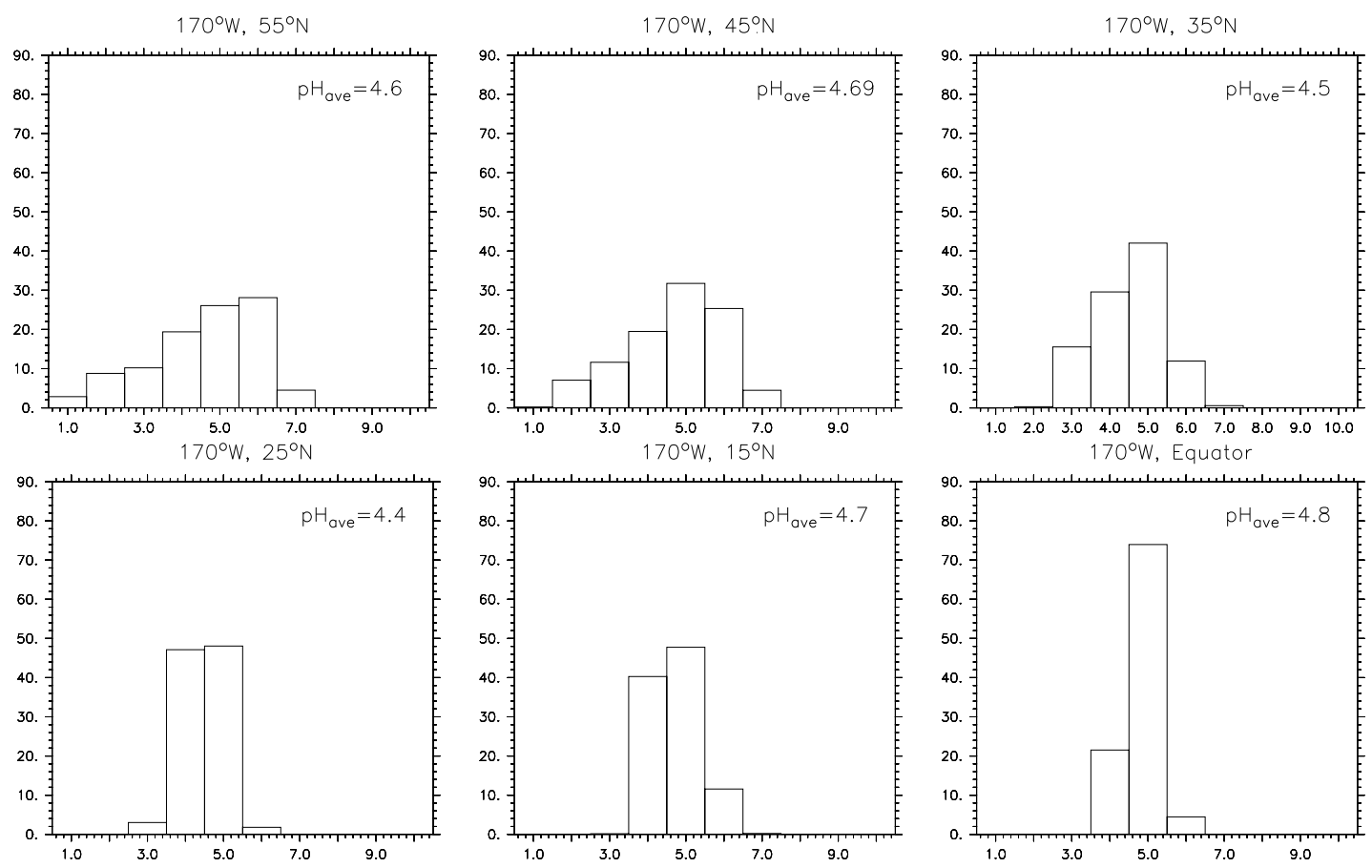

Fig. 12. PDFs of simulated boundary layer $\mathrm{pH}$-values at 6 locations in the Pacific at the same longitude. 

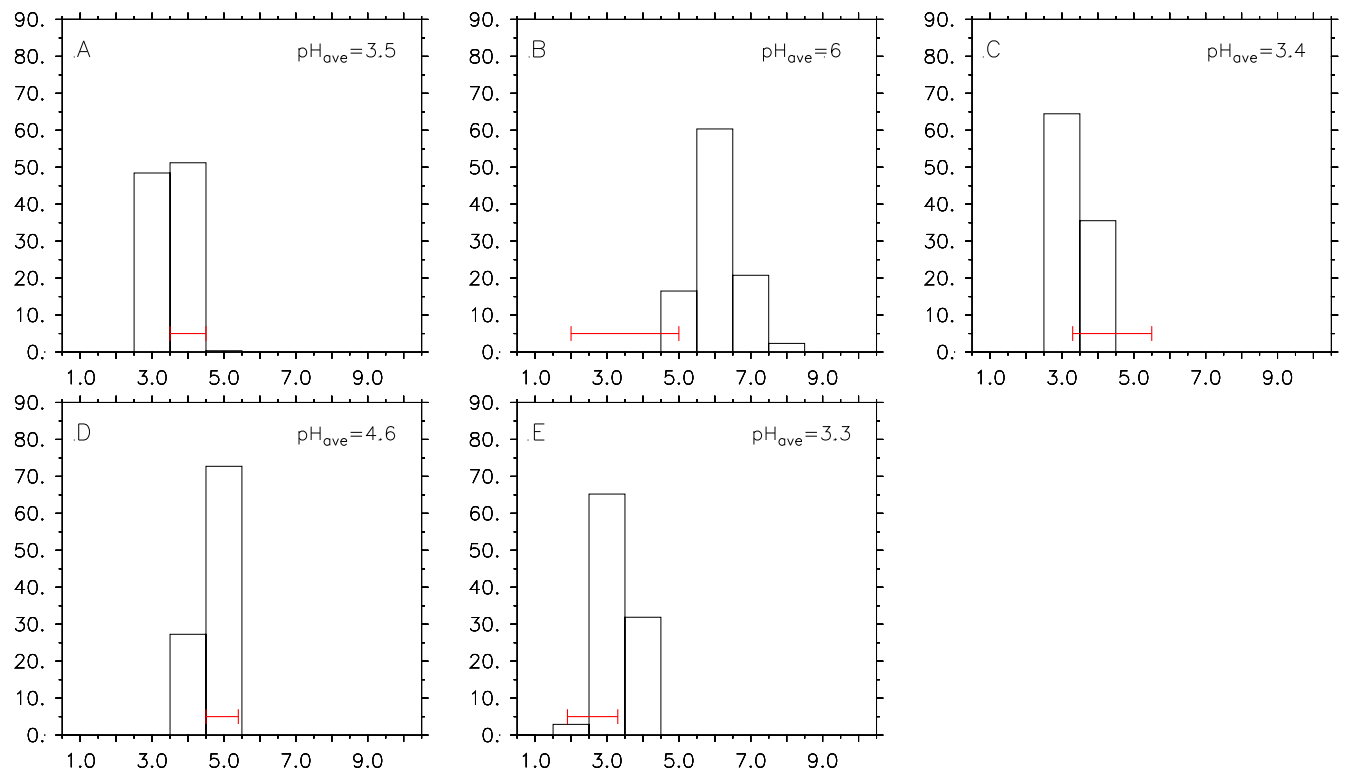

Fig. 13. Measured or inferred coarse mode aerosol $\mathrm{pH}$ and simulated probability density functions (PDFs) of $\mathrm{pH}$-values at locations and times of measurements listed in the Table 6. The red bars indicate the ranges of the $\mathrm{pH}$-values determined from the measurements. The letters A-E refer to the measurements listed in Table 6.

Figure 12 shows a frequency distribution of $\mathrm{pH}$-values along a north-south transect at $170^{\circ} \mathrm{W}$ over the Atlantic ocean from $55^{\circ} \mathrm{N}$ to the Equator. A distinct gradient from north to south is apparent in the spectrum of $\mathrm{pH}$-values. The $\mathrm{pH}$ variability is much higher in the North covering a pH-range of 1 to 7 . In contrast, south of $25^{\circ} \mathrm{N}$ the $\mathrm{pH}$ values only vary between $\mathrm{pH} 4$ and 6 . Even though the variability is high, the average $\mathrm{pH}$-values do not differ much: all averages range between 4.5 and 4.8 .

Figure 13 shows frequency distributions for the region and time of the year of the measurement campaigns as listed in Table 6. Since we did not simulate the same years, we show model results for the year 2000. Keene and Savoie (1999) report observations of $\mathrm{pH} 3.5$ to 4.5 for a site located directly at the coast of Bermuda (A), obtained in a campaign during April and May 1996. The simulated average pH of 3.5 is at the lower end of this observed range, but the distribution is narrow, in accordance to the narrow $\mathrm{pH}$ interval reported by Keene and Savoie (1999).

During a campaign in May 1997 at the same site (C) aerosol $\mathrm{pH}$-values ranged from approximately 3.3 to 5.3 (Keene et al., 2002). The simulation again yields $\mathrm{pH}$-values near the lower end of the measurements. The simulated width of the distribution is equally small as for the first campaign. In the simulation, emissions specified for the year 2000 have been used. As emissions increased during the 90 's, the lower $\mathrm{pH}$ values of the simulations can result from the higher emission of the simulation compared to the year where the measurements have acutally been taken.
Fridlind and Jacobson (2000) estimated coarse mode aerosol $\mathrm{pH}$ ranging from 2 to 5 from the measurements made during ACE 1 (B). Our simulation reproduces the wider range of acidification, but with an average $\mathrm{pH}$ of 6 the simulated aerosol $\mathrm{pH}$ is beyond the maximum value of the measurements.

Pszenny et al. (2004) report observations at Hawaii, USA, in September 1999 (D) with $\mathrm{pH}$-values ranging from 4.5 to 5.4. The simulation underestimates the $\mathrm{pH}$-values slightly, though reproduce the small standard deviation.

At the US east coast Keene et al. (2004) measured an aerosol $\mathrm{pH}$ of around 1.9-3.3 (E) for the aerosol size ranges which correspond to the coarse mode in the model. In this case the simulation reproduces very well the reported measurements.

The simulated $\mathrm{pH}$-values are slightly lower compared to those reported by Keene and Savoie (1999), Keene et al. (2002) and Pszenny et al. (2004), whereas they are close to the maximum reported by Keene et al. (2004) and higher than the maximum compared to Fridlind and Jacobson (2000). Since the first four publications use basically the same method to determine the aerosol $\mathrm{pH}$ and Fridlind and Jacobson (2000) use an equilibrium model, the differences might be explained by the uncertainties in the analysis of measured or inferred $\mathrm{pH}$. On the other hand, simulation results are shown for the year 2000 instead of the years of the respective campaigns. Given all these uncertainties in the simulation as well as in the measurements, we consider the sea salt aerosol $\mathrm{pH}$ to be reasonably well reproduced in our simulation. 


\section{Conclusions}

We present first results of a comprehensive AC-GCM simulation including gas and aerosol phase chemistry. Since this simulation aims at representing bromine chemistry and the largest boundary layer source of bromine is release from aerosol particles, we focus on the aerosol mass, number distributions and the aerosol $\mathrm{pH}$ in this first part of a series of articles. In our analysis we focus on coarse mode aerosols, because we had to limit the explicit chemistry calculation to one mode for numerical reasons. Since the coarse mode is the most important one for sea salt, it is reasonable to neglect the fine modes in this first global study.

Sea salt mass concentrations are overall slightly higher in the simulation compared to the observations. This can partly be attributed to the coarse model resolution. In contrast to this, the number concentrations are mostly underestimated by the model. The mean lifetime of coarse mode sea salt of 0.5 days derived from our simulation agrees very well with the AeroCom median.

It is difficult to measure the sea salt $\mathrm{pH}$, and only a few observations are available. Furthermore, $\mathrm{pH}$-measurements or inferences are associated with large uncertainties and based on assumptions, such as thermodynamic equilibrium of the particle and the effective Henry's law coefficient. Especially for the relatively large sea salt particles, the equilibrium assumption may be violated on time scales smaller than $1 \mathrm{~h}$. We conclude that within the range of these uncertainties the simulated aerosol $\mathrm{pH}$-values sufficiently accurately reproduce the observations, even if the $\mathrm{pH}$-values in remote regions have to be regarded as upper limits, as acidification of aerosols by organic acids is not taken into account in our modeling approach.

In summary, the basis for the simulation of aerosol phase chemistry and thus for bromine release from sea salt aerosol is provided by our model. In the following publications within this series the bromine chemistry of the marine aerosol will be analysed in detail.

Acknowledgements. We thank all MESSy developers for cooperation and support. The authors thank the "application support for high computer performance" team of the MPG computer center Garching, in particular I. Weidl, R. Hatzky, W. Nagel and H. Lederer. We are grateful for the availability of the observational data through the AeroCom data compilation by S. Guibert (LSCE/IPSL, France) and in particular to all scientists and technicians contributing to the data collection within EMEP, IMPROVE and AEROCE/SEAREX/DOE-EML. We thank Joe Prospero for providing detailed information about the AEROCE/SEAREX/DOE-EML measurement stations. We have used the Ferret program (http://www.ferret.noaa.gov) from NOAA's Pacific Marine Environmental Laboratory for creating the graphics in this paper. We thank the two anonymous referees for their valuable and constructive comments.

Edited by: M. Dameris

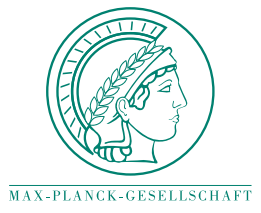

The publication of this article is financed by the Max Planck Society.

\section{References}

Balkanski, Y., Schulz, M., Claquin, T., Moulin, C., and Ginoux, P.: Global emissions of mineral aerosol: Formulation and validation using satellite imagery, Emission of Atmospheric Tracer Compounds, Kluwer Academic Publisher, Norwell, 253-282, 2003.

Bates, T. S., Kapustin, V. N., Quinn, P. K., Covert, D. S., Coffman, D. J., Mari, C., Dirkee, P. A., Bruyn, W. J. D., and Saltzman, E. S.: Processes controlling the distribution of aerosol particles in the lower marine boundary layer during the First Aerosol Charaterization Experiment (ACE1), J. Geophys. Res., 103, 16369 16383, 1998.

Brasseur, G. P. and Solomon, S.: Aeronomy of the middle atmosphere, Springer-Verlag, Dordecht, The Netherlends, 2005.

Buchholz, J.: Simulations of Physics and Chemistry of Polar Stratospheric Clouds with a General Circulation Model, Ph.D. thesis, Johannes Gutenberg-Universität, Fachbereich Physik, http://nbn-resolving.de/urn/resolver.pl?urn=urn:nbn:de: hebis:77-8187, 2005.

Damian, V., Sandu, A., Damian, M., Potra, F., and Carmichael, G. R.: The kinetic preprocessor KPP - a software enviroment for solving chemical kinetics, Comput. Chem. Eng., 26, 1567-1579, 2002.

Dentener, F., Kinne, S., Bond, T., Boucher, O., Cofala, J., Generoso, S., Ginoux, P., Gong, S., Hoelzemann, J. J., Ito, A., Marelli, L., Penner, J. E., Putaud, J.-P., Textor, C., Schulz, M., van der Werf, G. R., and Wilson, J.: Emissions of primary aerosol and precursor gases in the years 2000 and 1750 prescribed data-sets for AeroCom, Atmos. Chem. Phys., 6, 4321-4344, 2006, http://www.atmos-chem-phys.net/6/4321/2006/.

Duce, R. A.: Sea/air exchange of pollution and natural substances: The SEAREX Program, Proceedings of the WMO Technical Conference on Regional and Global Observation of Atmospheric Pollution Relative to Climate, Report, No. 14, WMO No. 549, World Meteorological Organization, Geneva, 1982.

Fitzgerald, J. W.: Marine Aerosols: A Review, Atmos. Environ., 25A, 533-545, 1991.

Fridlind, A. and Jacobson, M.: A study of gas-aerosol equilibrium and aerosol $\mathrm{pH}$ in the remote marine boundary layer during the First Aerosol Characterization Experiment (ACE 1), J. Geophys. Res., 105, 17 325-17 340, 2000.

Giorgetta, M. A., Manzini, E., and Roeckner, E.: Forcing of the quasi-biennial oscillation from a broad spectrum of atmospheric waves, Geophys. Res. Lett., 29, 1245, doi:10.1029/2002GL014756, 2002.

Giorgetta, M. A., Manzini, E., Roeckner, E., Esch, M., and Bengtson, L.: Climatology and forcing of the quasi-biennial oscillation in the MAECHAM5 model, J. Clim., 19, 3882-3901, 2006.

Gong, S. L., Barrie, L. A., Blanchet, J.-P., von Salzen, K., Lohmann, U., Lesins, G., Spacek, L., Zhang, L. M., Girard, E., Lin, H., Leaitch, R., Leighton, H., Chylek, P., and Huang, P.: Canadian Aerosol Module: A size-segregated simulation 
of atmospheric aerosol processes for climate and air quality models 1. Module development, J. Geophys. Res., 108, 4007, doi:10.1029/2001JD002002, 2003.

Guazzotti, S. A., Coffee, K. R., and Parther, K. A.: Continuous measurements of size-resolved particle chemistry during INDOEXIntensive Field Phase 99, J. Geophys. Res., 106, 28 607-28 627, 2001.

Guelle, W., Schulz, M., Balkanski, Y., and Dentener, F.: Influence of the source formulation on modeling the atmospheric global distribution of sea salt aerosol, J. Geophys. Res., 106, 27 50927 524, 2001.

Jeuken, A., Siegmund, P., Heijboer, L., Feichter, J., and Bengtson, L.: On the potential of assimilating meteorological analysis in a climate model for the purpose of model validation, J. Geophys. Res., 101, 16939-16950, 1996.

Jöckel, P., Sander, R., Kerkweg, A., Tost, H., and Lelieveld, J.: Technical Note: The Modular Earth Submodel System (MESSy) - a new approach towards Earth System Modeling, Atmos. Chem. Phys., 5, 433-444, 2005,

http://www.atmos-chem-phys.net/5/433/2005/.

Jöckel, P., Tost, H., Pozzer, A., Brühl, C., Buchholz, J., Ganzeveld, L., Hoor, P., Kerkweg, A., Lawrence, M. G., Sander, R., Steil, B., Stiller, G., Tanarhte, M., Taraborrelli, D., van Aardenne, J., and Lelieveld, J.: The atmospheric chemistry general circulation model ECHAM5/MESSy1: consistent simulation of ozone from the surface to the mesosphere, Atmos. Chem. Phys., 6, 50675104, 2006, http://www.atmos-chem-phys.net/6/5067/2006/.

Keene, W. C. and Galloway, J.: Consideration Regarding Sources for Formic and Acetic Acids in the Troposphere, J. Geophys. Res., 91, 14466-14 474, 1986.

Keene, W. and Savoie, D.: The pH of deliquesced sea-salt aerosol in polluted air, Geophys. Res. Lett., 25, 2181-2184, 1998.

Keene, W. and Savoie, D.: Correction to "The pH of deliquesced sea-salt aerosol in polluted air", Geophys. Res. Lett., 26, 13151316, 1999.

Keene, W., Pszenny, A., Maben, J., Stevenson, E., and Wall, A.: Closure evaluation of size-resolved aerosol $\mathrm{pH}$ in the New England coastal atmosphere during summer, J. Geophys. Res., 109, D23307, doi:10.1029/2004JD004801, 2004.

Keene, W. C., Sander, R., Pszenny, A. A., Vogt, R., Crutzen, P. J., and Galloway, J. N.: Aerosol pH in the marine boundary layer: A review and model evaluation, J. Aerosol Sci., 29, 339-356, 1998.

Keene, W. C., Pszenny, A. A. P., Maben, J. R., and Sander, R.: Variation of marine aerosol acidity with particle size, Geophys. Res. Lett., 29, 1101, doi:10.1029/2001GL013881, 2002.

Kerkweg, A., Buchholz, J., Ganzeveld, L., Pozzer, A., Tost, H., and Jöckel, P.: Technical Note: An implementation of the dry removal processes DRY DEPosition and SEDImentation in the Modular Earth Submodel System (MESSy), Atmos. Chem. Phys., 6, 4617-4632, 2006a,

http://www.atmos-chem-phys.net/6/4617/2006/.

Kerkweg, A., Sander, R., Tost, H., and Jöckel, P.: Technical note: Implementation of prescribed (OFFLEM), calculated (ONLEM), and pseudo-emissions (TNUDGE) of chemical species in the Modular Earth Submodel System (MESSy), Atmos. Chem. Phys., 6, 3603-3609, 2006b,

http://www.atmos-chem-phys.net/6/3603/2006/.

Kerkweg, A., Sander, R., Tost, H., Jöckel, P., and Lelieveld, J.: Technical Note: Simulation of detailed aerosol chemistry on the global scale using MECCA-AERO, Atmos. Chem. Phys., 7, 2973-2985, 2007,

http://www.atmos-chem-phys.net/7/2973/2007/.

Landgraf, J. and Crutzen, P.: An Efficient Method for Online Calculation of Photolysis and Heating Rates, J. Atmos. Sci., 55, 863878, 1998.

Lauer, A., Hendricks, J., Ackermann, I., Schell, B., Hass, H., and Metzger, S.: Simulating aerosol microphysics with the ECHAM/MADE GCM - Part I: Model description and comparison with observations, Atmos. Chem. Phys., 5, 3251-3276, 2005, http://www.atmos-chem-phys.net/5/3251/2005/.

Lewis, E. R. and Schwartz, S. E.: Sea Salt Aerosol Production: Mechanisms, Methods, Measurements and Models - A Critical Review, American Geophysical Union, Washington, D.C., 2004.

Maring, H., Savioe, D., Izaguirre, M., and Custals, L.: Vertical distribution of dust and sea-salt aerosol over Puerto Rico during PRIDE measured from a light aircraft, J. Geophys. Res., 108, 8587, doi:10.1029/2002JD002544, 2003.

Monahan, E. C.: The Role of Air-Sea Exchange in Geochemical Cycling, chap. The Ocean as a Source for Atmospheric Particles, D. Reidel Publishing Company, 129-163, 1986.

Murphy, D., Thomson, D., Middlebrook, A., and Schein, M.: In situ single-particle characterization at Cape Grim, J. Geophys. Res., 103, 16 485-16 491, 1998.

O'Dowd, C. D. and Smith, M. H.: Physicochemical Properties of Aerosols Over the Northeast Atlantic: Evidence for Wind-SpeedRelated Submicron Sea-Salt Aerosol Production, J. Geophys. Res., 98, 1137-1149, 1993.

Phinney, L., Leaitch, W. R., Lohmann, U., Boudires, H., Worsnop, D. R., Jayne, J. T., Toom-Sauntry, D., Wadleigh, M., Sharma, S., and Shantz, N.: Characterization of the aerosol over the subarctic north east Pacific Ocean, Deep-Sea Res., 53, 2410-2433, 2006.

Pierce, J. R. and Adams, P. J.: Global evaluation of CCN formation by direct emission of sea salt and growth of ultrafine sea salt, J. Geophys. Res., 111, D06203, doi:10.1029/2005JD006186, 2006.

Pozzer, A., Jöckel, P., Sander, R., Williams, J., Ganzeveld, L., and Lelieveld, J.: Technical Note: The MESSy-submodel AIRSEA calculating the air-sea exchange of chemical species, Atmos. Chem. Phys., 6, 5435-5444, 2006, http://www.atmos-chem-phys.net/6/5435/2006/.

Pozzer, A., Jöckel, P., Tost, H., Sander, R., Ganzeveld, L., Kerkweg, A., and Lelieveld, J.: Simulating organic species with the global atmospheric chemistry general circulation model ECHAM5/MESSy1: a comparison of model results with observations, Atmos. Chem. Phys., 7, 2527-2550, 2007, http://www.atmos-chem-phys.net/7/2527/2007/.

Pszenny, A. A. P., Moldanová, J., Keene, W. C., Sander, R., Maben, J. R., Martinez, M., Crutzen, P. J., Perner, D., and Prinn, R. G.: Halogen cycling and aerosol $\mathrm{pH}$ in the Hawaiian marine boundary layer, Atmos. Chem. Phys., 4, 147-168, 2004, http://www.atmos-chem-phys.net/4/147/2004/.

Roeckner, E., Bäuml, G., Bonaventura, L., Brokopf, R., Esch, M., Giorgetta, M., Hagemann, S., Kirchner, I., Kornblueh, L., Manzini, E., Rhodin, A., Schlese, U., Schulzweida, U., and Tompkins, A.: The atmospheric general circulation model ECHAM5, Tech. Rep. MPI-Report 349, Max Planck-Institute for Meteorology, Hamburg, http://www.mpimet.mpg.de/fileadmin/ publikationen/Reports/max_scirep_349.pdf , 2003. 
Roeckner, E., Brokopf, R., Esch, M., Giorgetta, M., Hagemann, S., Kornblueh, L., Manzini, E., Schlese, U., and Schulzweida, U.: The atmospheric general circulation model ECHAM5. PART II: Sensitivity of Simulated Climate to Horizontal and Vertical Resolution, Tech. Rep. MPI-Report 354, MPI for Meteorology, Hamburg, http://www.mpimet.mpg.de/fileadmin/publikationen/ Reports/max_scirep_354.pdf , 2004.

Sander, R. and Crutzen, P.: Model study indicating halogen activation and ozone destruction in polluted air masses transported to the sea, J. Geophys. Res., 101, 9121-9138, 1996.

Sander, R., Keene, W. C., Pszenny, A. A. P., Arimoto, R., Ayers, G. P., Baboukas, E., Cainey, J. M., Crutzen, P. J., Duce, R. A., H“nninger, G., Huebert, B. J., Maenhaut, W., Mihalopoulos, N., Turekian, V. C., and Van Dingenen, R.: Inorganic bromine in the marine boundary layer: a critical review, Atmos. Chem. Phys., 3, 1301-1336, 2003,

http://www.atmos-chem-phys.net/3/1301/2003/.

Sander, R., Kerkweg, A., J“ckel, P., and Lelieveld, J.: Technical note: The new comprehensive atmospheric chemistry module MECCA, Atmos. Chem. Phys., 5, 445-450, 2005, http://www.atmos-chem-phys.net/5/445/2005/.

Sandu, A. and Sander, R.: Technical note: Simulating chemical systems in Fortran90 and Matlab with the Kinetic PreProcessor KPP-2.1, Atmos. Chem. Phys., 6, 187-195, 2006, http://www.atmos-chem-phys.net/6/187/2006/.

Schulz, M., de Leeuw, G., and Balkanski, Y.: Emission of atmospheric trace compounds, Sea-salt aerosol source functions and emissions, Kluwer Academic, 333-359, 2004.

Smith, M. H. and Harrison, M.: The Sea Spray Generation Function, J. Aerosol Sci., 29, Suppl. 1, S189-S190, 1998.

Spracklen, D. V., Pringle, K. J., Carslaw, K. S., Chipperfield, M. P., and Mann, G. W.: A global off-line model of size-resolved aerosol microphysics: I. Model development and prediction of aerosol properties, Atmos. Chem. Phys., 5, 2227-2252, 2005, http://www.atmos-chem-phys.net/5/2227/2005/.

Stier, P., Feichter, J., Kinne, S., Kloster, S., Vignati, E., Wilson, J., Ganzeveld, L., Tegen, I., Werner, M., Balkanski, Y., Schulz, M., Boucher, O., Minikin, A., and Petzold, A.: The aerosolclimate model ECHAM5-HAM, Atmos. Chem. Phys., 5, 11251156, 2005, http://www.atmos-chem-phys.net/5/1125/2005/.
Textor, C., Schulz, M., Guibert, S., Kinne, S., Balkanski, Y., Bauer, S., Berntsen, T., Berglen, T., Boucher, O., Chin, M., Dentener, F., Diehl, T., Easter, R., Feichter, H., Fillmore, D., Ghan, S., Ginoux, P., Gong, S., Grini, A., Hendricks, J., Horowitz, L., Huang, P., Isaksen, I., Iversen, I., Kloster, S., Koch, D., Kirkevåg, A., Kristjansson, J. E., Krol, M., Lauer, A., Lamarque, J. F., Liu, X., Montanaro, V., Myhre, G., Penner, J., Pitari, G., Reddy, S., Seland, Ø., Stier, P., Takemura, T., and Tie, X.: Analysis and quantification of the diversities of aerosol life cycles within AeroCom, Atmos. Chem. Phys., 6, 1777-1813, 2006, http://www.atmos-chem-phys.net/6/1777/2006/.

Tost, H., Jöckel, P., Kerkweg, A., Sander, R., and Lelieveld, J.: Technical note: A new comprehensive SCAVenging submodel for global atmospheric chemistry modelling, Atmos. Chem. Phys., 6, 565-574, 2006, http://www.atmos-chem-phys.net/6/565/2006/.

Tost, H., Jöckel, P., and Lelieveld, J.: Influence of different convection parameterisations in a GCM, Atmos. Chem. Phys., 6, 54755493, 2006, http://www.atmos-chem-phys.net/6/5475/2006/.

Tost, H., Jöckel, P., and Lelieveld, J.: Lightning and convection parameterisations - uncertainties in global modelling, Atmos. Chem. Phys., 7, 4553-4568, 2007, http://www.atmos-chem-phys.net/7/4553/2007/.

Vehkamäki, H., nad I. Napari, M. K., Lehtinen, K., Timmreck, C., Noppel, M., and Laaksonen, A.: An improved parameterization for sulfuric acid-water nucleation rates for tropospheric and stratospheric conditions, J. Geophys. Res., 107, 4622, doi:10.1029/2002JD002184, 2002.

Vignati, E., Wilson, J., and Stier, P.: M7: An efficient size-resolved aerosol microphysics module for large-scale aerosol transport, J. Geophys. Res., 109, D22202, doi:10.1029/2003JD004486, 2004.

von Glasow, R. and Sander, R.: Variation of sea salt aerosol pH with relative humidity, Geophys. Res. Lett., 28, 247-250, 2001.

von Glasow, R., Sander, R., Bott, A., and Crutzen, P.: Modeling halogen chemistry in the marine boundary layer 1 . Cloud-free MBL, J. Geophys. Res., 107, 4341, doi:10.1029/2001JD000942, 2002.

Wagner, T., Leue, C., Wenig, M., Pfeilsticker, K., and Platt, U.: Spatial and temporal distribution of enhanced boundary layer $\mathrm{BrO}$ concentrations measured by GOME instrument onboard ERS-2, J. Geophys. Res., 106, 24 225-24 235, 2001.

Wilson, J., Cuvelier, C., and Raes, F.: A modeling study of global mixed aerosol fields, J. Geophys. Res., 106, 34 081-34 108, 2001. 